Leave this area blank for abstract info.

From One to Two Quaternary Centers: Ester or Nitrile $\alpha$-Alkylation applied to Bioactive Alkaloids

Nicholas Voute ${ }^{\mathrm{a}}$, Andrew R. Neal ${ }^{\mathrm{a}}$, Federico Medda ${ }^{\mathrm{a}}$, Craig A. Johnston ${ }^{\mathrm{a}}$, Alexandra M. Z. Slawin ${ }^{\mathrm{a}}$, Nicholas J. Westwood ${ }^{\text {a }}$

School of Chemistry and Biomedical Sciences Research Complex, University of St. Andrews and EaStCHEM, St Andrews, Fife, Scotland, KY16 9ST (UK).

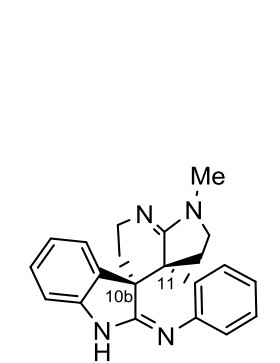

Dehaloperophoramidine

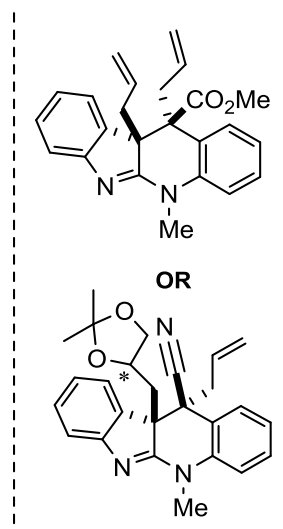

Highly diastereoselective construction of intermediates towards the synthesis of dehaloperophoramidine and the communesins.
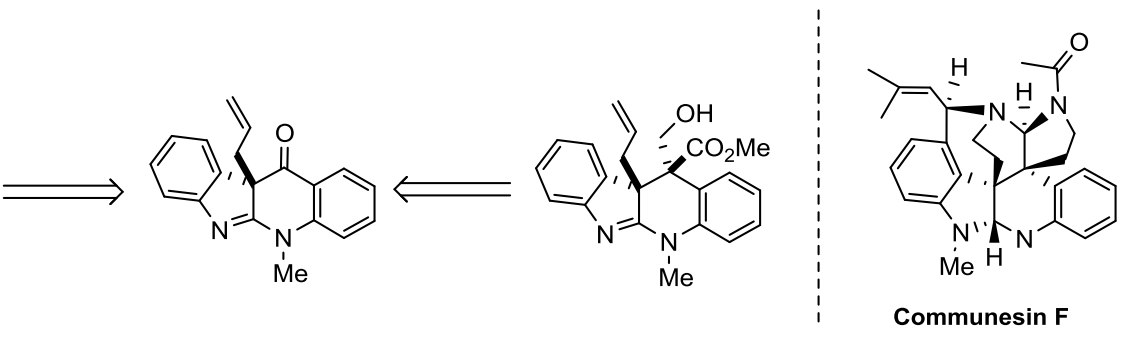


\title{
From One to Two Quaternary Centers: Ester or Nitrile $\alpha$-Alkylation applied to Bioactive Alkaloids
}

\author{
Nicholas Voute ${ }^{a}$, Andrew R. Neal ${ }^{\mathrm{a}}$, Federico Medda ${ }^{\mathrm{a}}$, Craig A. Johnston ${ }^{\mathrm{a}}$, Alexandra M. Z. Slawin ${ }^{\mathrm{a}}$, \\ Nicholas J. Westwood, ${ }^{\text {a, }}$
}

${ }^{a}$ School of Chemistry and Biomedical Sciences Research Complex, University of St Andrews and EaStCHEM, North Haugh, St Andrews, Fife, KY16 9ST, UK.

\section{ARTICLE INFO}

\section{Article history:}

Received

Received in revised form

Accepted

Available online

\section{Keywords:}

Dehaloperophoramidine

Diastereoselective

Quaternary

Stereocenter

\section{ABSTRACT}

The synthesis of all-carbon quaternary centers remains a challenge. Here we describe studies on the formation of two adjacent all-carbon quaternary centers in the context of the planned synthesis of the bioactive natural products perophoramidine and the communesins. In one approach the key step involves ester-alkylation using either allyl bromide or formaldehyde as the electrophile. An unexpected rapid auto-oxidation reaction during the synthesis of the alkylation substrates limited the scalability of this approach. In a second route, alkylation of a nitrile-containing precursor was planned. The use of the TosMIC reagent on a complex substrate gave the nitrile for alkylation. The assignment of the relative stereochemistry of the products was done through the extensive use of small molecule X-ray crystallography.

\section{Introduction}

The natural product perophoramidine (1) and its dehalogenated derivative $\mathbf{2}$ were first reported by Ireland in 2002. ${ }^{1}$ These compounds are structurally related to another family of alkaloids known as the communesins (for example 3F, Figure 1). ${ }^{2}$ Since their isolation, 1-3 have proved an inspiration to synthetic chemists resulting in numerous total syntheses and a wide range of elegant approaches. $^{3-5}$
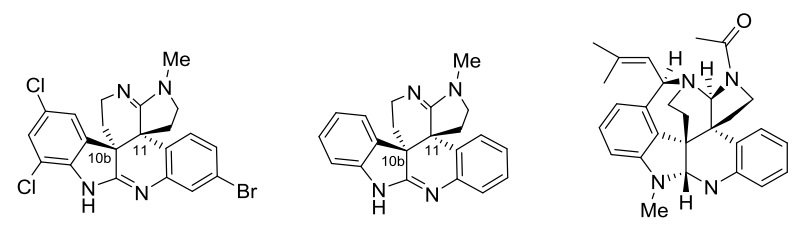

(+)-Perophoramidine (1)

Dehaloperophoramidine (2)

Communesin F (3F)

Figure 1: Structures of the natural products (1-3F) relevant to this work.

These natural products all possess an indolo[2,3-b]quinoline core structure but it is the vicinal all-carbon quaternary centers that present the major synthetic challenge. Early work on the synthesis of dehaloperophoramidine (2) by Rainier ${ }^{4 a}$ involved alkylation of lactam 4 to give 5 under basic conditions via enolate 6 (Scheme 1a). This reaction occurred to give a single diastereomer with addition of allyl iodide occurring from the opposite side to the $\mathrm{CH}_{2} \mathrm{CH}_{2} \mathrm{NR}_{2}$ group on $\mathrm{C}-10 \mathrm{~b}$. In addition, Weinreb has reported the conversion of $\mathbf{7}$ to $\mathbf{8}$ via enolate $9 .^{5 \mathrm{c}}$ In Weinreb's example it was argued that the bulky BOM protected primary alcohol at C12a controlled C11 - alkylation of 9 leading to the allyl group being

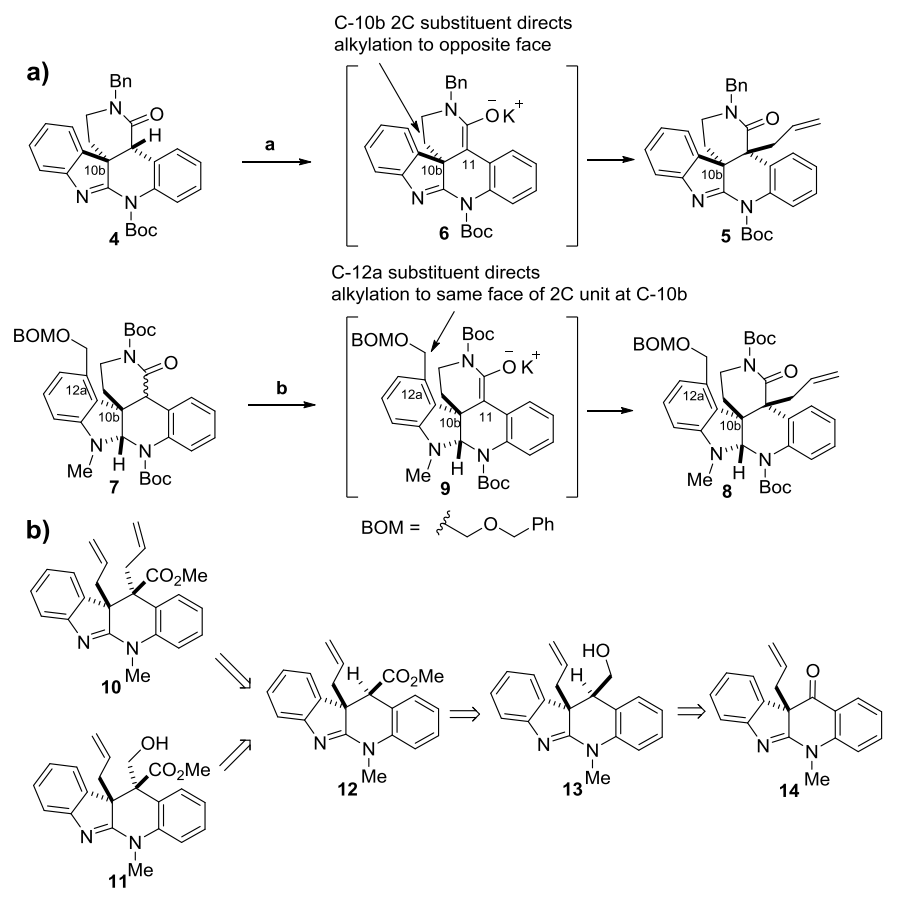

Scheme 1: a) The previously reported alkylation methods by Rainier ${ }^{4 a}$ and Weinreb $^{5 c}$; Reagents and conditions:a) $\mathrm{KO}^{t} \mathrm{Bu}$, allyl iodide, THF, $0{ }^{\circ} \mathrm{C} 89 \%$, b) $\mathrm{KO}{ }^{t} \mathrm{Bu}$, allyl iodide, $\mathrm{THF},-78^{\circ} \mathrm{C}-\mathrm{rt}, 87 \%$. b) Two proposed methods for installing the required all-carbon quaternary stereocenters from our ketone $\mathbf{1 4}$. 
directed onto the same face as the existing $\mathrm{CH}_{2} \mathrm{CH}_{2} \mathrm{NR}_{2}$ group at $\mathrm{C}-10 \mathrm{~b}$. These results suggest that the stereochemical outcome of alkylation at $\mathrm{C} 11$, in the absence of a C12a-substituent, is highly likely to lead to the new substituent being place on the opposite face to the $\mathrm{CH}_{2} \mathrm{CH}_{2} \mathrm{NR}_{2}$ group at $\mathrm{C}-10 \mathrm{~b}$. We therefore considered an approach towards both ester $\mathbf{1 0}$ (in a plan to prepare dehaloperophoramidine (2)) and ester $\mathbf{1 1}$ (for the communesins) via a common intermediate $\mathbf{1 2}$ (Scheme 1b). Ester $\mathbf{1 2}$ could be constructed from alcohol $\mathbf{1 3}$ which could itself be formed from ketone 14. ${ }^{6}$ Here we describe the outcome of this plan and discuss a series of interesting issues that arose during these studies.

\section{Results and Discussion}

We have previously reported the synthesis of ketone 14 (Scheme 1b). ${ }^{6}$ In this new work, preliminary investigations involved nucleophilic addition to $\mathbf{1 4}$ to assess the stereochemical outcome (Scheme 2). Reduction of 14 with $\mathrm{NaBH}_{4}$ led to alcohol 15 in high yield $(89 \%)$ as a single diastereoisomer. The relative stereochemistry of $\mathbf{1 5}$ was confirmed by X-ray crystallographic analysis and indicated hydride attack on $\mathbf{1 4}$ had occurred on the opposite face to the allyl group at $\mathrm{C}-10 \mathrm{~b}$, as expected. Furthermore, treatment of the $N$-benzylated analogue $\mathbf{1 6}$ led to the formation of $17(95 \%)$ as a single diastereoisomer. The relative stereochemistry of $\mathbf{1 7}$ was proposed to be the same as $\mathbf{1 5}$ (see Table $\mathrm{S} 1$ for ${ }^{1} \mathrm{H}$ NMR comparison of $\mathbf{1 5}$ and $\mathbf{1 7}$ and further discussion).

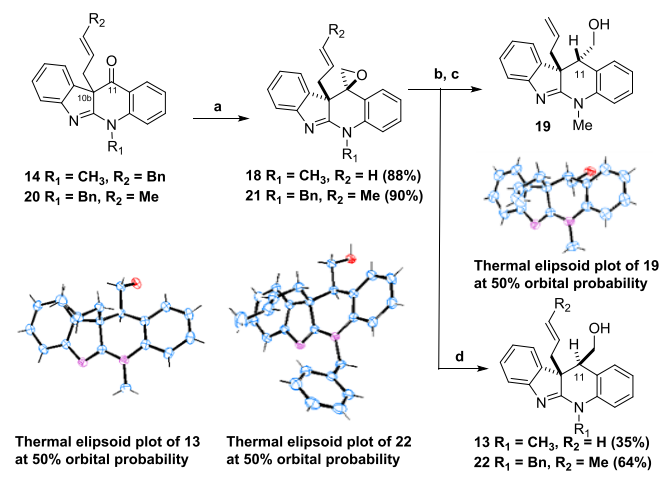

Scheme 2: Diastereoselective reductions of ketones 14 and 16. In each case the nucleophile approached from the opposite face to the allyl group at $\mathrm{C}-10 \mathrm{~b}$. The structure of $\mathbf{1 5}$ was confirmed by X-ray crystallographic analysis and this was used to infer the relative stereochemistry in $\mathbf{1 7}$.

This result encouraged us to continue our approach to installing the all-carbon quaternary stereocenters in $\mathbf{1}$ and $\mathbf{2}$ using the $\mathrm{C} 10 \mathrm{~b}$ stereocenter as the control unit. In brief, as this section of our approach has been previously described in a communication format, ${ }^{4 \mathrm{~d}} \mathbf{1 4}$ was converted to 18 using $\mathrm{MeLiBr}$ in the presence of chloroiodomethane (Scheme 3). With 18 in hand, attempts were made to perform an acid-catalysed rearrangement of the epoxide. The addition of 5 equivalents of $\mathrm{BF}_{3} \square \mathrm{OEt}_{2}$ to $\mathbf{1 8}$ led to a complex mixture of products. However, treatment of the crude sample with $\mathrm{NaBH}_{4}$ and subsequent recrystallisation from $\mathrm{CDCl}_{3} /$ hexane afforded alcohol 19. The relative configuration of 19 was assigned using X-ray crystallographic analysis. Alternatively, reductive opening of 18 with 2.5 equivalents of $\mathrm{BF}_{3} \square \mathrm{OEt}_{2}$ in the presence of $\mathrm{NaBH}_{3} \mathrm{CN}$ gave alcohol $\mathbf{1 3}$ in an unoptimised $35 \%$ yield after recrystallisation from methanol. X-ray crystallographic analysis confirmed the structure of $\mathbf{1 3}$ and demonstrated that it was the C11 epimer of alcohol 19. Analogous reaction conditions were applied to ketone 20 (Scheme 3). The change in the N-R protecting group from methyl to benzyl was required to enable a late stage deprotection to give the required unprotected amidine. ${ }^{4 \mathrm{~d}}$ The change from the allyl to the crotyl side chain was part of one potential solution to the challenge of developing an asymmetric approach to $2{ }^{6}$ Ketone $\mathbf{2 0}$ was converted to $\mathbf{2 1}$ in an optimized
$90 \%$ yield and underwent successful reductive epoxide opening to alcohol 22.

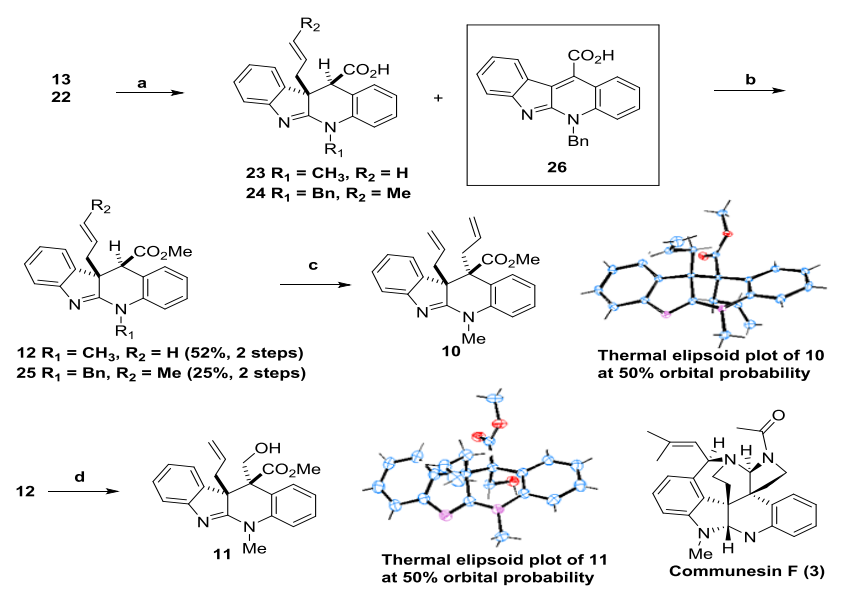

Scheme 3: Formation of alcohols 19, 13 and 22. The structures of these compounds were confirmed by X-ray crystallographic analysis. Reaction conditions: a MeLi- $\mathrm{LiBr}, \mathrm{ClCH}_{2} \mathrm{I}$, THF, $-78{ }^{\circ} \mathrm{C}, 0.5$ h, rt, 12 h; b BF $3 \square \mathrm{OEt}_{2}$, THF, $-78{ }^{\circ} \mathrm{C}, 3 \mathrm{~h}$; c NaBH $4, \mathrm{MeOH}, \mathrm{rt}, 2 \mathrm{~h}$; d $\mathrm{BF}_{3} \mathrm{OEt}_{2}, \mathrm{NaBH}_{3} \mathrm{CN},-78^{\circ} \mathrm{C}$-rt, $18 \mathrm{~h}$.

Again, X-ray crystallographic analysis of $\mathbf{2 2}$ confirmed the relative stereochemistry of the new $\mathrm{C}-11$ stereocenter.

With alcohols 13 and 22 in hand, attempts were made to install the required all-carbon quaternary stereocenters at $\mathrm{C} 10 \mathrm{~b}$ and $\mathrm{C} 11$. Alcohol 13 underwent Jones oxidation to carboxylic acid 23, followed by methylation to give ester 12 in 52\% yield ( 2 steps, Scheme 4). Loss of product likely occurred during the work up stage as the zwitterionic nature of $\mathbf{2 3}$ probably renders it soluble in the aqueous phase. Encouragingly, alkylation of 12 with allyl bromide under basic conditions afforded the desired ester $\mathbf{1 0}$ as a single diastereoisomer in $59 \%$ yield. X-ray crystallographic analysis of $\mathbf{1 0}$ confirmed that alkylation had been directed to the opposite face of the existing $\mathrm{C}-10 \mathrm{~b} \mathrm{CH}_{2} \mathrm{CH}_{2} \mathrm{NR}_{2}$ group, as expected. Therefore $\mathbf{1 0}$ was viewed as a potentially suitable intermediate en route to dehaloperophoramidine (2).
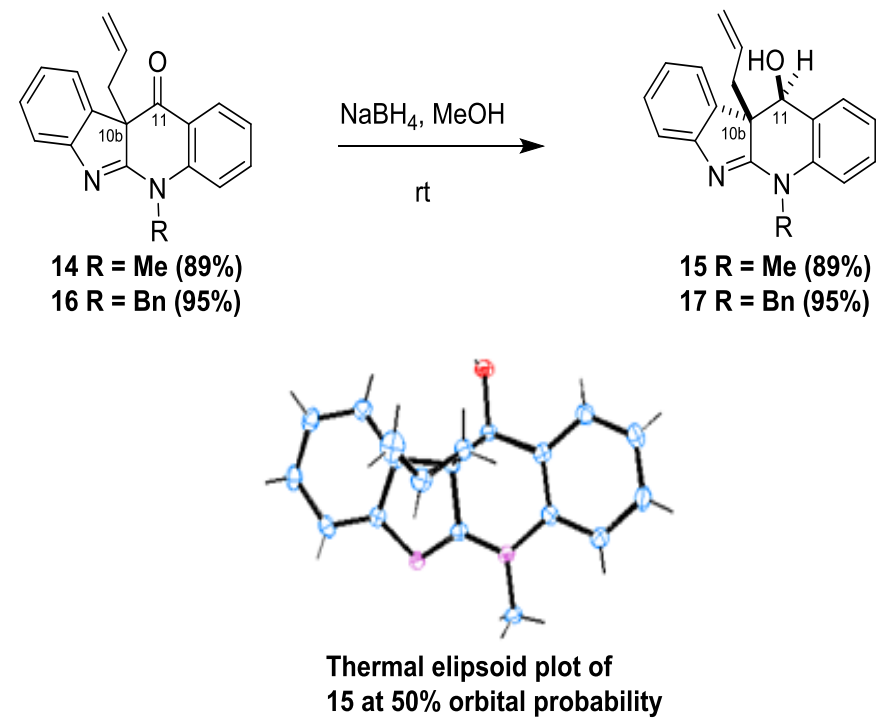

Scheme 4: Formation of all-carbon quaternary stereocenters with the desired relative stereochemistry in dehaloperophoramidine and the communesins. Reagents and conditions: a $\mathrm{CrO}_{3}, \mathrm{H}_{2} \mathrm{SO}_{4}, \mathrm{H}_{2} \mathrm{O}, \mathrm{Me}_{2} \mathrm{CO}$, rt; b $\mathrm{Me}_{3} \mathrm{SiCHN}_{2}, \mathrm{MeOH}$, rt; c LiHMDS, allyl bromide, THF, $-78{ }^{\circ} \mathrm{C}$ to rt, $16 \mathrm{~h}, 59 \%$; d LDA, $\mathrm{H}_{2} \mathrm{CO}$, THF, $-78^{\circ} \mathrm{C}$ to rt, $1.5 \mathrm{~h}, 76 \%$.

Ester 12 was also considered as a possible intermediate towards members of the communesin family of natural products. Alkylation of 12 with formaldehyde in the presence of LDA 
afforded $\mathbf{1 1}$ in good yield (76\%) as a single diastereoisomer. Xray crystallographic analysis confirmed the structure of $\mathbf{1 1}$ and showed that it possessed 1-carbon units at different oxidation levels that afforded $\mathbf{1 1}$ in good yield $(76 \%)$ as a single diastereoisomer. X-ray crystallographic analysis confirmed the structure of 11 and showed that it possessed 1-carbon units at different oxidation levels that were either syn- $\left(\mathrm{CO}_{2} \mathrm{Me}\right)$ or anti$\left(\mathrm{CH}_{2} \mathrm{OH}\right)$ to the allyl group at $\mathrm{C}-10 \mathrm{~b}$. Selective functionalisation of the ester would be required to generate the necessary syn-2carbon unit required in the communesins.

However, when the analogous reactions were carried out on the crotyl-containing alcohol 22, Jones oxidation of carboxylic acid $\mathbf{2 4}$, followed by methylation to ester $\mathbf{2 5}$ could only be achieved in an overall yield of $25 \%$. The low yield rendered this approach unsuitable for the planned approach to 2 . Unfortunately, the yield could not be improved despite an extensive screen of reaction conditions and oxidising agents (Table S2). Further analysis of the Jones oxidation reaction of $\mathbf{2 2}$ by LCMS and LRMS indicated significant accumulation of a degradation product during the reaction $(\mathrm{m} / \mathrm{z}=352.96)$. After isolation via semi-preparative HPLC, this compound was tentatively assigned as achiral 26 (Scheme 4). ${ }^{1} \mathrm{H}$ NMR analysis of $\mathbf{2 6}$ indicated loss of the crotyl group. Furthermore, the diastereotopic benzyl $\underline{\mathrm{C}}_{2}$ protons present in $\mathbf{2 2}$ (two doublets) now appeared as a singlet in $\mathbf{2 6}$ (see SI for a further discussion and one proposed mechanism for this reaction). As the presence of the crotyl group in $\mathbf{2 2}$ appeared to have a detrimental effect on the yield of $\mathbf{2 3}$, it was decided to modify this group by oxidative cleavage (Scheme 5). This transformation would be required at some stage in any synthesis of $\mathbf{2}$ to remove the one excess carbon atom.

Dihydroxylation followed by oxidative cleavage of the alkene in 20, followed by in-situ reduction of the intermediate aldehyde afforded 27 in high yield (88\%). Alcohol 27 was initially $O$ benzylated before undergoing epoxide formation to give $\mathbf{2 8}$ in an analogous manner to the synthesis of $\mathbf{1 8}$ and $\mathbf{2 1}$ (Scheme 3). Disappointingly, the conversion of $\mathbf{2 8}$ to alcohol $\mathbf{2 9}$ in the presence of $\mathrm{BF}_{3} \square \mathrm{OEt}_{2}$ could not be achieved and a complex mixture of unassignable products was isolated. This was likely due to initial Lewis-acid mediated $O$-benzyl deprotection prior to degradation of the starting material. To overcome this issue, TBDPS protected epoxide 30 was synthesized. Gratifyingly, $\mathbf{3 0}$ underwent the desired reductive epoxide opening to give 31 in a 55\% yield. Due to its acid labile silyl protecting group (TBDPS), 31 was deemed unsuitable for oxidation under the highly acidic Jones conditions.

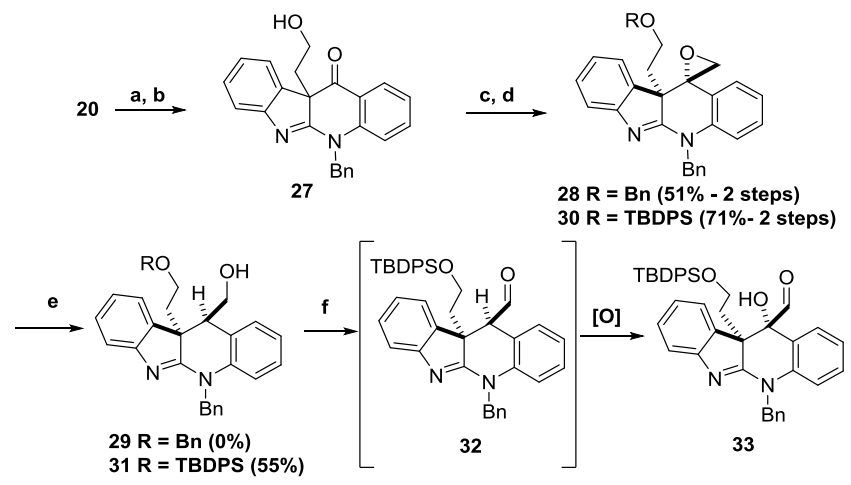

Scheme 5: Synthesis of $\mathbf{3 1}$ and unexpected air oxidation of intermediate $\mathbf{3 2}$ to $\mathbf{3 3}$. Reagents and conditions: a $\mathrm{OsO}_{4}, \mathrm{NMO}, \mathrm{THF}: \mathrm{H}_{2} \mathrm{O}(9: 1), 18 \mathrm{~h}$, rt. b $\mathrm{PhI}(\mathrm{OAc})_{2}, \mathrm{DCM}, 2 \mathrm{~h}$, rt then $\mathrm{NaBH}(\mathrm{OAc})_{3}$, EtOAc, $2 \mathrm{~h}, \mathrm{rt}, 88 \%$ (2 steps). c i) Benzyl TCA, TMSOTf, DCM, $0{ }^{\circ} \mathrm{C}-\mathrm{rt}$, $4 \mathrm{~h}$; c ii) TPDBS-Cl, imidazole, DCM, rt, 1 h. d $\mathrm{ClICH}_{2}$, MeLi:LiBr, THF, $6 \mathrm{~h},-78{ }^{\circ} \mathrm{C}-$ rt, $51 \%$ for 28 (2 steps); $71 \%$ for 30 ( 2 steps). e $\mathrm{BF}_{3} \cdot \mathrm{Et}_{2} \mathrm{O}, \mathrm{NaBH}_{3} \mathrm{CN}, \mathrm{THF},-78^{\circ} \mathrm{C}-\mathrm{rt}$, $16 \mathrm{~h}, 55 \%$. f DMP, $\mathrm{CDCl}_{3}$, rt, $48 \mathrm{~h}, 65 \%$.

Instead, Dess-Martin periodinane (DMP) was chosen in an attempt to form aldehyde 32. Interestingly, whilst 32 was the initial product formed upon the addition of 1.2 equivalents of DMP to $\mathbf{3 1}$ (full consumption of the starting material was observed after 0.5 hours, Figure SI1) it was found that $\alpha$-hydroxylation occurred at C-11 to form 33 after extended reaction times (48 h, Figure SI1. See Figure SI2 for further discussion of the oxidation and assignment of the stereochemistry in 33). Furthermore, $\alpha$ hydroxylation was still found to occur even after isolation and rapid purification by column chromatography of aldehyde 32. This indicated 32 was air sensitive and that molecular oxygen was the likely source of the undesired oxidation. Air oxidation at benzylic positions $\alpha$ - to an aldehyde has been reported previously in the total synthesis of Fredericamycin A by Boger and co-workers. ${ }^{7}$

Whilst the transformation of $\mathbf{3 1}$ to $\mathbf{3 3}$ was intriguing, it prevented further progress towards the desired natural products 1-3. Having struggled to develop a reproducible and scalable method for the construction of the all-carbon quaternary stereocenters via the above methods, a new approach was investigated. Reassessment of the structure of key intermediate $\mathbf{1 2}$ (Scheme 1b) showed that whilst the presence of the ester moiety adjacent to C-11 ultimately permitted alkylation to give $\mathbf{1 0}$ and was at the correct oxidation level for this atom in $\mathbf{2}$, significant further development of the ester would be required to incorporate the necessary nitrogen atoms. It was therefore proposed that the installation of a cyano group at $\mathrm{C}$ 11 could achieve the analogous acidification of the $\mathrm{C}-11$ proton to facilitate alkylation and that it may be possible to incorporate the cyano nitrogen into advanced intermediates (Scheme 6a). After initial attempts to convert the alcohol in $\mathbf{1 7}$ to a cyano group (via a $\mathrm{C}-11$ bromide) proved unsuccessful, it was decided to try and incorporate the cyano group using tosylmethyl isocyanide (TosMIC). An initial attempt to convert the ketone in $\mathbf{1 4}$ to the cyano group with TosMIC failed to yield the desired nitrile $\mathbf{3 4}$ (Scheme 6b). Instead, the achiral 35, in which the allyl group had migrated from $\mathrm{C}-10 \mathrm{~b}$ to $\mathrm{C}-11$, was isolated in $61 \%$ yield (see SI for further discussion on the structural assignment of $\mathbf{3 5}$ and two possible mechanisms).
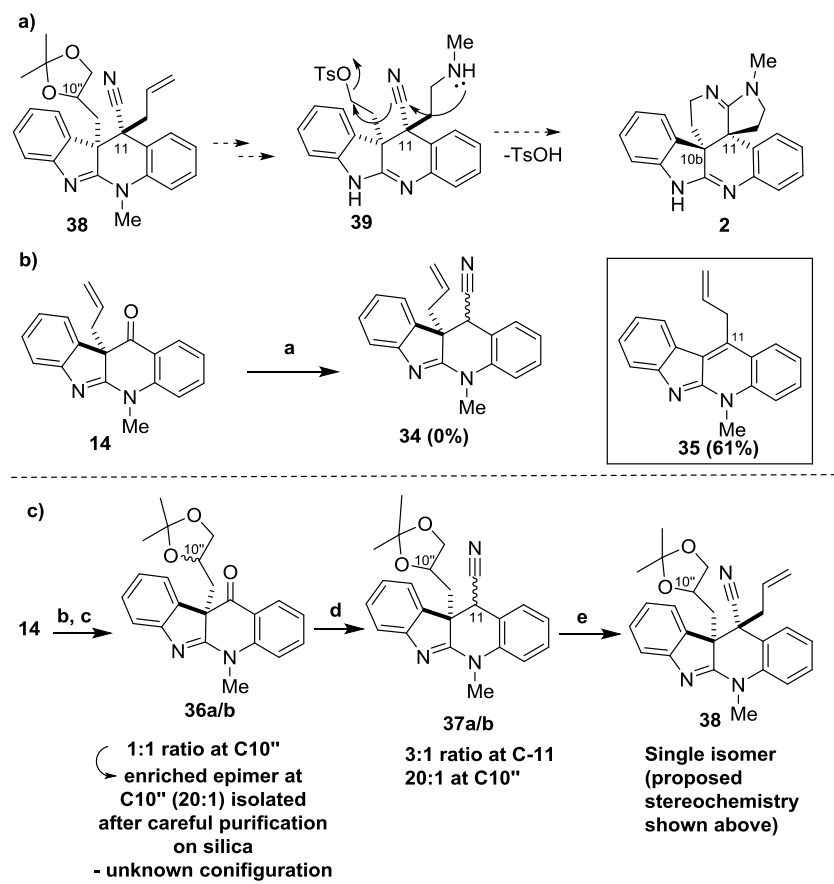

Scheme 6: A) Synthesis of achiral 35. Reagents and conditions: a TosMIC, DME $t$ $\mathrm{BuOK}, 0{ }^{\circ} \mathrm{C}$ to $\mathrm{rt}, 1.5 \mathrm{~h}$; B) Synthesis of allyl-nitrile 38 and proposed di-cyclisation of target intermediate 39. Reagents and conditions: b OsO $\mathrm{O}_{4}, \mathrm{NMO}, \mathrm{THF}, \mathrm{H}_{2} \mathrm{O}, \mathrm{rt}, 24 \mathrm{~h}$, PPTS; c $\mathrm{Me}_{2} \mathrm{C}(\mathrm{OMe})_{2}, \mathrm{CH}_{2} \mathrm{Cl}_{2}, \mathrm{rt}, 48 \mathrm{~h}, 70 \%$ (2 steps); d TosMIC, t-BuOK, t-BuOH, DME, $0{ }^{\circ} \mathrm{C}$ to rt, $1 \mathrm{~h}$; e LiHMDS, allyl bromide, THF, $-78{ }^{\circ} \mathrm{C}$ to rt, $34 \%$ (2 steps).

As the presence of the allyl side chain at C-10b again appeared to be providing an alternative reaction pathway, it was decided to 
functionalise this group prior to attempting the TosMIC-mediated reductive cyanation (Scheme 6c). Dihydroxylation of ketone 14, followed by protection of the resulting diol via acetal formation with 2,2-dimethoxypropane led to formation of $\mathbf{3 6}$ and its C10", epimer. Careful chromatographic purification of the resulting the diastereomeric mixture $\mathbf{3 6 a} / \mathbf{b}$, gave a highly enriched sample of 36a (20:1). The relative stereochemistry at $\mathrm{C} 10$ "' in $\mathbf{3 6}$ a could not be assigned. Reductive cyanation of $\mathbf{3 6 a}$ gave $37 \mathbf{a} / \mathbf{b}$ as a mixture of $\mathrm{C}-11$ epimers in ratio of $3: 1$ with only trace signals corresponding to the $\mathrm{C} 10$ ' ' epimers being observed in the ${ }^{1} \mathrm{H}$ NMR spectrum.

Finally, allylation of the diastereomeric mixture of $37 \mathbf{a} / \mathbf{b}$ was achieved by treatment with allyl bromide in the presence of LiHMDS to give 38 (34\%, 2 steps) as essentially a single isomer after purification. Although $\mathbf{3 8}$ was obtained as a single diastereoisomer, it was not possible to obtain X-ray crystallographic data to assign the relative stereochemistry (the structure currently assigned to $\mathbf{3 8}$ is tentative and is based on the assumption that alkylation was directed by the $\mathrm{CH}_{2} \mathrm{CH}$-acetal group on $\mathrm{C}-10 \mathrm{~b}$ in the absence of a C12-substituent (see Scheme 1)).

Having successfully synthesized allyl-nitrile 38, future work will focus on the synthesis of intermediate 39 (Scheme 6a) via functionalization of the $\mathrm{C}-3$ units at $\mathrm{C}-10 \mathrm{~b}$ and $\mathrm{C}-11$ and demethylation of the amidine moiety. It is hoped that $\mathbf{3 9}$ could be a direct precursor to $\mathbf{2}$ upon undergoing a double cyclisation to construct the second required amidine.

\section{Conclusions}

In conclusion, we have described the construction of all-carbon quaternary stereocenters within intermediates aimed at both dehaloperophoramidine (2) and the communesins. The reactions involved have included highly diastereoselective base mediated alkylation at the $\mathrm{C}-11$ position of ester $\mathbf{1 2}$ with both allyl bromide and formaldehyde. In addition, a 2-steps protocol for the construction of all-carbon quaternary stereocenters via TosMIC addition to $\mathbf{3 6}$ and alkylation is described. Further investigations into the synthesis of the target natural products via these intermediates will be reported in due course.

\section{Experimental}

\section{General methods}

All chemicals and solvents were purchased from Sigma Aldrich (UK) or Alfa-Aesar and used without further purification. All reactions were carried out under a positive pressure of nitrogen or argon in flame or oven-dried glassware. Thin layer chromatography (TLC) analysis was performed on silica precoated SIL G-25 UV 254 sheets (layer: $0.25 \mathrm{~mm}$ silica gel with fluorescent indicator $\mathrm{UV}_{254}$, Alugram, UK). Compounds were visualized by UV light (UV lamp, model UVGL-58, Mineralight LAMP, Multiband UV-254/365 nm) and stained with potassium permanganate. Flash column chromatography was carried out on silica gel $(40-63 \mu \mathrm{m}$, Fluorochem, UK). Melting points were measured with an Electrothermal 9100 capillary melting point apparatus and are uncorrected. Fourier Transform infra-red spectra (FT-IR) were acquired on a Perkin Elmer paragon 1000 FT spectrometer. Absorption maxima are reported in wavenumbers $\left(\mathrm{cm}^{-1}\right)$. Unless otherwise stated, ${ }^{1} \mathrm{H}$ and ${ }^{13} \mathrm{C}$ NMR spectra were measured at room temperature $(298 \mathrm{~K})$ on a Bruker DPX 400 $\left({ }^{1} \mathrm{H}=400 \mathrm{MHz},{ }^{13} \mathrm{C}=100 \mathrm{MHz}\right) ;$ Bruker Avance 300 $\left({ }^{1} \mathrm{H}=300 \mathrm{MHz},{ }^{13} \mathrm{C}=75 \mathrm{MHz}\right)$ and a Bruker Avance 500 $\left({ }^{1} \mathrm{H}=500.1 \mathrm{MHz},{ }^{13} \mathrm{C}=125 \mathrm{MHz}\right)$. Deuterated solvents were used and ${ }^{1} \mathrm{H}$ NMR chemical shifts were internally referenced to $\mathrm{CHCl}_{3}(7.26 \mathrm{ppm})$ in chloroform- $\mathrm{d}_{1}$ solution. Chemical shifts are expressed as $\delta$ in unit of ppm and coupling constants are recorded in $\mathrm{Hz}$. Data processing was carried out using TOPSPIN 2 NMR version (Bruker UK, Ltd) or MestreNova 9.0 program (Bruker UK Ltd). In ${ }^{1} \mathrm{H}$ NMR assignment the multiplicity used is indicated by the following abbreviations: $\mathrm{s}=$ singlet, $\mathrm{d}=$ doublet, $\mathrm{dd}=$ doublet of doublets, $\mathrm{t}=$ triplet, $\mathrm{q}=$ quartet, $\mathrm{m}=$ multiplet, $\mathrm{brs}=$ broad singlet. Signals of protons and carbons were assigned, as far as possible, by using the following two-dimensional NMR spectroscopy techniques: $\left[{ }^{1} \mathrm{H}-{ }^{1} \mathrm{H}\right]$ COSY, $\left[{ }^{1} \mathrm{H}^{-13} \mathrm{C}\right]$ HSQC (Heteronuclear Single Quantum Coherence) and long range $\left[{ }^{1} \mathrm{H}-\right.$ ${ }^{13} \mathrm{C}$ ] HMBC (Heteronuclear Multiple Bond Connectivity). Mass spectrometry analysis (electrospray mode, ES; chemical ionization mode, CI) were performed by Ms Caroline Hosburgh and were recorded on a high performance orthogonal acceleration reflecting TOF mass spectrometer operating in positive and negative mode, coupled to a Waters 2975 HPLC.

\section{Experimental procedures}

\section{( \pm )-10b-allyl-5-methyl-5,11-dihydro-10bH-indolo[2,3- b]quinoline-11-ol (15)}

$\mathrm{NaBH}_{4}(164 \mathrm{mg}, 4.34 \mathrm{mmol})$ was added to a solution of 14 (250 $\mathrm{mg}, 0.867 \mathrm{mmol})$ and $\mathrm{MeOH}(10 \mathrm{~mL})$. After 2 hours, water $(2$ $\mathrm{mL}$ ) was added and the $\mathrm{MeOH}$ was evaporated at reduced pressure. The aqueous residue was extracted with $\mathrm{CH}_{2} \mathrm{Cl}_{2}(3 \times 5$ $\mathrm{mL})$. The combined extracts were dried $\left(\mathrm{MgSO}_{4}\right)$ and the $\mathrm{CH}_{2} \mathrm{Cl}_{2}$ was concentrated in vacuo. The residue was purified by flash chromatography $(10 \%$ to $20 \% \mathrm{EtOAc/hexane)}$ the afford the title compound $\mathbf{1 5}$ as a colourless crystalline solid (224 mg, 0.771 mmol, 89\%). Crystals suitable for X-ray analysis were obtained from EtOH. Mp 181-182 ${ }^{\circ} \mathrm{C}$; IR (KBr) $v_{\max }: 3416,3076,1557 \mathrm{~cm}^{-}$ 1; HRMS (CI) m/z calcd for $\mathrm{C}_{19} \mathrm{H}_{19} \mathrm{~N}_{2} \mathrm{O} 291.1497$, found 291.1496; ${ }^{1} \mathrm{H}$ NMR $\left(300 \mathrm{MHz}, \mathrm{CDCl}_{3}\right) \delta 7.60(\mathrm{ddd}, J=7.5,1.5,1.0 \mathrm{~Hz}, 1 \mathrm{H})$, $7.47(\mathrm{~d}, J=7.5 \mathrm{~Hz}, 1 \mathrm{H}), 7.38-7.24(\mathrm{~m}, 3 \mathrm{H}), 7.13(\mathrm{td}, J=7.5,1.0$ $\mathrm{Hz}, 1 \mathrm{H}), 7.05-6.99$ (m, 2H), 5.26-5.12 (m, 1H), 4.98 (d, $J=7.5$ $\mathrm{Hz}, 1 \mathrm{H}), 4.78-4.71(\mathrm{~m}, 2 \mathrm{H}), 3.57(\mathrm{~s}, 3 \mathrm{H}), 2.94(\mathrm{~d}, J=7.5 \mathrm{~Hz}, 1 \mathrm{H})$, $2.63(\mathrm{dd}, J=13.5,7.0 \mathrm{~Hz}, 1 \mathrm{H}), 2.32(\mathrm{dd}, J=13.5,7.5 \mathrm{~Hz}, 1 \mathrm{H})$; ${ }^{13} \mathrm{C}$ NMR $\left(75 \mathrm{MHz}, \mathrm{CDCl}_{3}\right) \delta 173.1,155.8,140.1,137.2,132.7$, $128.94,128.87,126.7,125.8,123.1,123.0,122.6,118.5,117.5$, $114.3,72.1,57.0,33.6,32.9$

\section{( \pm )-10b-allyl-5-benzyl-10b,11-dihydro-5H-indolo[2,3-} b]quinolin-11-ol (17)

$\mathrm{NaBH}_{4}$ (164 mg, $\left.4.34 \mathrm{mmol}\right)$ was added to a solution of $\mathbf{1 6}(100$ $\mathrm{mg}, 0.275 \mathrm{mmol})$ and $\mathrm{MeOH}(5 \mathrm{~mL})$. After 2 hours, water $(5 \mathrm{~mL})$ was added and the mixture was diluted with DCM $(10 \mathrm{~mL})$. The organic layer was washed with brine; dried $\left(\mathrm{MgSO}_{4}\right)$ then concentrated in vacuo. The residue was purified by flash chromatography $(10 \%$ to $20 \%$ EtOAc/hexane) the afford the title compound 17 as a colourless crystalline solid $(91 \mathrm{mg}, 0.249 \mathrm{mmol}$, 91\%). IR (ATR) $v_{\max }: 3293,1631,1553 \mathrm{~cm}^{-1}$; HRMS (ESI) $\mathrm{m} / \mathrm{z}$ calcd. for $\mathrm{C}_{25} \mathrm{H}_{23} \mathrm{~N}_{2} \mathrm{O} 367.1810$, found 367.1813 ; ${ }^{1} \mathrm{H}$ NMR $(500$ $\left.\mathrm{MHz} \mathrm{CDCl}_{3}\right) \delta 7.59(\mathrm{dt}, J=7.5,1.5 \mathrm{~Hz}, 1 \mathrm{H}), 7.50(\mathrm{dd}, J=7.0,1.0$ $\mathrm{Hz}, 1 \mathrm{H}), 7.36-7.27(\mathrm{~m}, 6 \mathrm{H}), 7.26-7.17(\mathrm{~m}, 2 \mathrm{H}), 7.08$ (dtd, $J=$ $13.5,7.5,1.0 \mathrm{~Hz}, 2 \mathrm{H}), 6.92(\mathrm{dd}, J=8.0,1.0 \mathrm{~Hz}, 1 \mathrm{H}), 5.77$ (d, $J=$ $16.5 \mathrm{~Hz}, 1 \mathrm{H}), 5.31-5.20(\mathrm{~m}, 1 \mathrm{H}), 5.04(\mathrm{~d}, J=7.0 \mathrm{~Hz}, 1 \mathrm{H}), 4.94$ $(\mathrm{d}, J=16.5 \mathrm{~Hz}, 1 \mathrm{H}), 4.87-4.80(\mathrm{~m}, 2 \mathrm{H}), 2.77(\mathrm{dd}, J=14.0,7.0$ $\mathrm{Hz}, 1 \mathrm{H}), 2.67(\mathrm{~d}, J=7.0 \mathrm{~Hz}, 1 \mathrm{H}), 2.44(\mathrm{dd}, J=14.0,7.5 \mathrm{~Hz}, 1 \mathrm{H})$; ${ }^{13} \mathrm{C}$ NMR $\left(126 \mathrm{MHz}, \mathrm{CDCl}_{3}\right) \delta 173.1,155.9,139.6,137.4,136.9$, $132.8,128.8,127.4,126.7,126.6,125.6,123.3,123.1,122.7$, $118.7,117.8,115.2,72.1,57.0,49.8,33.4$ 
( \pm )-10b-allyl-11-hydroxymethyl-5-methyl-5,11-dihydro-10bHindolo[2,5-b]quinoline (19)

An impure sample of SI1 $(7 \mathrm{mg})$ was dissolved in $\mathrm{MeOH}(0.5 \mathrm{~mL})$ and $\mathrm{NaBH}_{4}(5 \mathrm{mg}, 0.132 \mathrm{mmol})$ was added. After $2 \mathrm{~h}$, water $(0.5$ $\mathrm{mL})$ was added and the mixture was extracted with $\mathrm{CH}_{2} \mathrm{Cl}_{2}(3 \mathrm{x} 1$ $\mathrm{mL})$. The combined extracts were dried $\left(\mathrm{MgSO}_{4}\right)$ and the solvent was evaporated at reduced pressure to give the title compound 19 as a colourless solid $(7 \mathrm{mg})$. A crystal suitable for X-ray analysis was obtained from $\mathrm{CDCl}_{3} /$ hexane. IR (film) $v_{\max }$ : 3192,1556 , $1493,1469,1455,1403,1219,1132,1063,922,753,737 \mathrm{~cm}^{-1}$; HRMS (CI) $\mathrm{m} / \mathrm{z}$ calcd for $\mathrm{C}_{20} \mathrm{H}_{20} \mathrm{~N}_{2} \mathrm{O} 304.1576$, found 304.1577; ${ }^{1} \mathrm{H}$ NMR $\left(300 \mathrm{MHz}, \mathrm{CDCl}_{3}\right) \delta$ 7.36-7.21 (m, 5H), 7.08-6.99 (m, $3 \mathrm{H}), 5.52-5.38(\mathrm{~m}, 1 \mathrm{H}), 4.98-4.94(\mathrm{~m}, 1 \mathrm{H}), 4.81-4.74(\mathrm{~m}, 1 \mathrm{H})$, $3.61(\mathrm{~s}, 3 \mathrm{H}), 3.51(\mathrm{dd}, J=14.0,8.5 \mathrm{~Hz}, 1 \mathrm{H}), 3.39-3.31(\mathrm{~m}, 2 \mathrm{H})$, $2.47(\mathrm{dd}, J=13.5,8.0 \mathrm{~Hz}, 1 \mathrm{H}), 2.25$ (dd, $J=13.5,7.0 \mathrm{~Hz}, 1 \mathrm{H})$.

(土)-10b-allyl-11-hydroxymethyl-5-methyl-5,11-dihydro-10bHindolo[2,5-b]quinoline (13)

A stirred mixture of $\mathbf{1 8}(560 \mathrm{mg}, 1.84 \mathrm{mmol})$ and $\mathrm{NaBH}_{3} \mathrm{CN}(291$ $\mathrm{mg}, 4.63 \mathrm{mmol})$ in THF $(20 \mathrm{~mL})$, maintained under an argon atmosphere, was cooled to $-10{ }^{\circ} \mathrm{C}$. A solution of $\mathrm{BF}_{3}$. $\mathrm{OEt}_{2}(0.51$ $\mathrm{mL}, 4.06 \mathrm{mmol})$ in THF $(5 \mathrm{~mL})$ was added over a period of 20 min. After 2 hours, an additional portion of $\mathrm{BF}_{3} . \mathrm{OEt}_{2}(0.12 \mathrm{~mL}$, $0.955 \mathrm{mmol})$ in THF $(1 \mathrm{~mL})$ was added and stirring was continued for 1 hour at $-10{ }^{\circ} \mathrm{C}$. $\mathrm{NaHCO}_{3(\mathrm{aq})}(50 \mathrm{~mL})$ was added and the reaction mixture was allowed to warm to room temperature. The aqueous solution was extracted with $\mathrm{CH}_{2} \mathrm{Cl}_{2}(4 \times 30 \mathrm{~mL})$, the combined extracts were washed with brine $(50 \mathrm{~mL})$, dried $\left(\mathrm{MgSO}_{4}\right)$, and the $\mathrm{CH}_{2} \mathrm{Cl}_{2}$ was evaporated at reduced pressure. The residue was crystallised from $\mathrm{MeOH} /$ water to afford the title compound 13 as a colourless crystalline solid (196 mg, 0.644 mmol, 35\%). Crystals from $\mathrm{MeOH}$ were suitable for X-ray analysis. Mp 190-191 ${ }^{\circ} \mathrm{C}$; Anal. calcd for $\mathrm{C}_{20} \mathrm{H}_{20} \mathrm{~N}_{2} \mathrm{O}: \mathrm{C}, 78.92 ; \mathrm{H}$, 6.62; N, 9.20. Found: C, 78.99; H, 6.66; N, 9.53; IR (KBr) $v_{\max }$ : 3201, 2928, 2876, 1616, 1557, 1495, 1472, 1456, 1401, 1316, $1222,1139,1105,1051,986,931,809,758,652,499 \mathrm{~cm}^{-1}$; HRMS (CI) $\mathrm{m} / \mathrm{z}$ calcd for $\mathrm{C}_{20} \mathrm{H}_{20} \mathrm{~N}_{2} \mathrm{O} 304.1576$, found $304.1569 ;{ }^{1} \mathrm{H}$ NMR $\left(300 \mathrm{MHz}, \mathrm{CDCl}_{3}\right) \delta 7.68(\mathrm{ddd}, J=8.0,1.5,1.0 \mathrm{~Hz}, 1 \mathrm{H}), 7.26-$ $7.23(\mathrm{~m}, 4 \mathrm{H}), 7.14-6.98(\mathrm{~m}, 3 \mathrm{H}), 5.10-4.96(\mathrm{~m}, 1 \mathrm{H}), 4.73-4.62(\mathrm{~m}$, $3 \mathrm{H}), 4.48-4.39(\mathrm{~m}, 1 \mathrm{H}), 3.58(\mathrm{~s}, 3 \mathrm{H}), 3.12-3.07(\mathrm{~m}, 1 \mathrm{H}) 2.38-2.35$ $(\mathrm{m}, 2 \mathrm{H}), 2.01(\mathrm{dd}, J=7.5,3.5,1 \mathrm{H}) ;{ }^{13} \mathrm{C} \mathrm{NMR}\left(75 \mathrm{MHz}, \mathrm{CDCl}_{3}\right) \delta$ $173.9,156.0,141.4,136.7,132.6,128.8,128.2,127.4,125.4$, $123.7,123.2,122.3,118.2,117.4,114.6,61.7,54.3,44.2,35.0$, 33.1 .

\section{(土)-5,10b-dihydro-10b-crotyl-5-benzyl-10bH-indolo[2,3- b] quinolin-11-one (20)}

A solution of alkoxide was prepared by the careful addition of sodium (1.72 g, $75 \mathrm{mmol}$, 2 eq.) to 3-buten-2-ol (21.0 g, $243 \mathrm{mmol}, 3.2$ eq.) in THF ( $5 \mathrm{~mL})$. This solution was added to a stirring solution of SI2 (10 g, $37.5 \mathrm{mmol}, 1$ eq.; the synthesis of SI2 has been reported previously $\left.{ }^{4 \mathrm{~d}}\right)$ in THF $(200 \mathrm{~mL})$. The resulting reaction mixture was stirred at room temperature for $18 \mathrm{~h}$. Saturated aqueous $\mathrm{NH}_{4} \mathrm{Cl}$ was then added $(100 \mathrm{~mL})$ and the solvent removed at reduced pressure. The resulting residue was suspended in water $(100 \mathrm{~mL})$ and extracted with DCM $(3 \times 100 \mathrm{~mL})$. The combined organic extracts were dried $\left(\mathrm{MgSO}_{4}\right)$ and the solvent removed at reduced pressure. The crude material was dissolved in THF $(150 \mathrm{~mL})$ and stirred at reflux for $5 \mathrm{~h}$. After cooling to room temperature, the residue was purified by column chromatography (Hexane/EtOAc, 95:5 to 90:10) to afford the desired product $\mathbf{2 0}$ as a yellow microcrystalline powder (8.50 g, $22.5 \mathrm{mmol}, 60 \%)$. Mp 148-150 ${ }^{\circ} \mathrm{C}$; IR (KBr) $v_{\max } \mathrm{cm}^{-1}$ 1697, 1558, 1469; HRMS $\left(\mathrm{ES}^{+}\right) \mathrm{m} / z$ calcd for $\mathrm{C}_{23} \mathrm{H}_{20} \mathrm{O}_{4} \mathrm{Na}$ 401.1630, found 401.1614; ${ }^{1} \mathrm{H}$ NMR $\delta_{\mathrm{H}}\left(300 \mathrm{MHz}, \mathrm{CDCl}_{3}\right) 7.95$ (dd, $J=7.5,1.5 \mathrm{~Hz}, 1 \mathrm{H}), 7.70(\mathrm{dd}, J=7.5 \mathrm{~Hz}, 0.5 \mathrm{~Hz}, 1 \mathrm{H}), 7.53-$ $7.21(\mathrm{~m}, 8 \mathrm{H}), 7.20-6.97(\mathrm{~m}, 3 \mathrm{H}), 5.92(\mathrm{~d}, J=16.5 \mathrm{~Hz}, 1 \mathrm{H}), 5.35-$ $5.19(\mathrm{~m}, 1 \mathrm{H}), 5.11-4.96(\mathrm{~m}, 2 \mathrm{H}), 2.87(\mathrm{dd}, J=13.5 \mathrm{~Hz}, 6.5 \mathrm{~Hz}$, $1 \mathrm{H}), 2.46(\mathrm{dd}, J=13.5 \mathrm{~Hz}, J=8.0 \mathrm{~Hz}, 1 \mathrm{H}), 1.53(\mathrm{dd}, J=6.0 \mathrm{~Hz}$, $J=0.5 \mathrm{~Hz}, 3 \mathrm{H}) ;{ }^{13} \mathrm{C} \mathrm{NMR} \delta_{\mathrm{C}}\left(100 \mathrm{MHz}, \mathrm{CDCl}_{3}\right) 192.9,172.3$, $153.5,144.8,136.9,133.6,131.6,129.0,128.7,128.4,127.8$, 127.6, 126.7 (2C), 124.8, 123.1, 122.6, 122.5, 119.3, 118.7, 115.5, $66.5,49.6,44.3,17.9$.

(土)-10b-crotyl-5-benzyl-5,11-dihydro-10bH-indolo[2,5b] quinolin-11-spiro-2'-oxirane (21)

To a mixture of 20 (4.90 g, $12.9 \mathrm{mmol}, 1$ eq.) in THF (50 mL) at $78{ }^{\circ} \mathrm{C}$ was added slowly MeLi-LiBr $(12.2 \mathrm{~mL}$ of a $1.5 \mathrm{M}$ solution, $19.4 \mathrm{mmol}$, $1.5 \mathrm{eq})$ over a period of 20 minutes. Chloroiodomethane (1.22 mL, $19.4 \mathrm{mmol}, 1.5$ eq.) was added and the reaction mixture stirred for $30 \mathrm{~min}$ at $-78^{\circ} \mathrm{C}$ before allowing to warm to room temperature. After stirring for $18 \mathrm{~h}$ at room temperature, saturated aqueous $\mathrm{NH}_{4} \mathrm{Cl}$ solution $(50 \mathrm{~mL})$ was added and the solvent removed at reduced pressure. Water $(50 \mathrm{~mL})$ and $\mathrm{Et}_{2} \mathrm{O}(50 \mathrm{ml})$ were added, the organic phase was separated and the aqueous phase further extracted with $\mathrm{Et}_{2} \mathrm{O}$ $(3 \times 50 \mathrm{~mL})$. The combined organic extracts were dried $\left(\mathrm{MgSO}_{4}\right)$ and filtered through a plug of silica. The resulting organic solution was left to slowly evaporate at ambient temperature until nearly dry ( $c a .10 \mathrm{~mL}$ of $\mathrm{Et}_{2} \mathrm{O}$ remaining). The desired product $\mathbf{2 1}$ was obtained as large colourless crystals $(4.45 \mathrm{~g}, 11.35 \mathrm{mmol}, 88 \%)$. $\mathrm{Mp} 138-141{ }^{\circ} \mathrm{C}$; IR (KBr) $v_{\max } 3029,2938,1813,1689,1558,1491$ $\mathrm{cm}^{-1}$; HRMS $\mathrm{m} / z\left(\mathrm{ES}^{+}\right)$calcd for $\mathrm{C}_{27} \mathrm{H}_{25} \mathrm{~N}_{2} \mathrm{O}$ 393.1967, found 393.1956; ${ }^{1} \mathrm{H}$ NMR $\delta_{\mathrm{H}}\left(400 \mathrm{MHz}, \mathrm{CDCl}_{3}\right) 7.43-7.16(\mathrm{~m}, 10 \mathrm{H})$, 7.07-6.97 (m, 2H), $6.91(\mathrm{dd}, J=8.0 \mathrm{~Hz}, 0.5 \mathrm{~Hz}, 1 \mathrm{H}), 5.91(\mathrm{~d}$, $J=16.5 \mathrm{~Hz}, 1 \mathrm{H}), 5.33-5.21(\mathrm{~m}, 1 \mathrm{H}), 4.97-4.83(\mathrm{~m}, 2 \mathrm{H}), 3.07(\mathrm{~d}$, $J=5.5 \mathrm{~Hz}, 1 \mathrm{H}), 2.81(\mathrm{dd}, J=14.0,6.0 \mathrm{~Hz}, 1 \mathrm{H}), 2.62(\mathrm{dd}, J=14.0$, $8.5 \mathrm{~Hz} 1 \mathrm{H}), 2.53(\mathrm{~d}, J=5.5 \mathrm{~Hz}, 1 \mathrm{H}), 1.45(\mathrm{~d}, J=6.0 \mathrm{~Hz}, 3 \mathrm{H}) ;{ }^{13} \mathrm{C}$ NMR $\delta_{\mathrm{C}}\left(100 \mathrm{MHz}, \mathrm{CDCl}_{3}\right) 172.6,155.5,141.5,137.0,134.6$, $129.7,129.4,128.9,128.8,127.4,126.6,124.2,123.8,123.5$, $123.3,122.8,122.8,118.0,115.1,60.2,55.3,53.6,49.9,37.3$, 17.9.

(土)-10b-crotyl-11-hydroxymethyl-5-benzyl-5,11-dihydro-10bHindolo[2,5-b]quinoline (22)

To a stirring solution of $21(5.30 \mathrm{~g}, 13.5 \mathrm{mmol}, 1$ eq.) in THF $(150 \mathrm{~mL})$ at $-78^{\circ} \mathrm{C}$ was added $\mathrm{NaBH}_{3} \mathrm{CN}(2.12 \mathrm{~g}, 33.7 \mathrm{mmol}$, 2.5 eq.). A solution of $\mathrm{BF}_{3}$. $\mathrm{OEt}_{2}(6.78 \mathrm{~mL}, 54.0 \mathrm{mmol}, 4$ eq. $)$ was then added over a period of $20 \mathrm{~min}$ and the resulting reaction mixture allowed to warm to room temperature. After stirring for $18 \mathrm{~h}$ at room temperature, the reaction was quenched by the addition of water $(50 \mathrm{~mL})$ and the aqueous solution extracted with DCM $(4 \times 50 \mathrm{~mL})$. The combined organic extracts were washed with brine $(50 \mathrm{~mL})$, dried $\left(\mathrm{MgSO}_{4}\right)$, and the solvent removed at reduced pressure to afford the crude product. Purification by basic silica gel column chromatography (Hexane/EtOAc, 80:20) afforded the desired product $\mathbf{2 2}$ as a yellow oily solid (3.49 g, $8.64 \mathrm{mmol}, 64 \%$ ). Crystals suitable for X-ray analysis were obtained by slow evaporation from methanol. Mp 130-133 ${ }^{\circ} \mathrm{C}$; IR $(\mathrm{KBr}) v_{\max } 3375,3029,2931,1615,1558,1494,1454,1408,1326$, $1214102 \mathrm{~cm}^{-1}$; HRMS $\left(\mathrm{ES}^{+}\right) \mathrm{m} / z$ calcd for $\mathrm{C}_{27} \mathrm{H}_{26} \mathrm{~N}_{2} \mathrm{ONa}$ 419.1943, found 417.1939; ${ }^{1} \mathrm{H}$ NMR $\delta_{\mathrm{H}}\left(300 \mathrm{MHz}, \mathrm{CDCl}_{3}\right) 7.68-$ $7.62(\mathrm{~d}, J=7.5 \mathrm{~Hz}, 1 \mathrm{H}), 7.42-7.16(\mathrm{~m}, 9 \mathrm{H}), 7.11-6.98(\mathrm{~m}, 2 \mathrm{H})$, $6.93(\mathrm{dd}, J=8.0,1.0 \mathrm{~Hz}, 1 \mathrm{H}), 5.79(\mathrm{~d}, J=16.5 \mathrm{~Hz}, 1 \mathrm{H}), 5.25-5.09$ $(\mathrm{m}, 1 \mathrm{H}), 4.86(\mathrm{~d}, J=16.5 \mathrm{~Hz}, 1 \mathrm{H}), 4.76-4.58(\mathrm{~m}, 2 \mathrm{H}), 4.52-4.35$ (m, $1 \mathrm{H}), 3.15(\mathrm{~d}, J=5.0 \mathrm{~Hz}, 1 \mathrm{H}), 2.40$ (d, $J=7.0 \mathrm{~Hz}, 2 \mathrm{H}), 1.94$, 
$1.38(\mathrm{dd}, J=6.5 \mathrm{~Hz}, 1.5 \mathrm{~Hz}, 3 \mathrm{H}) ;{ }^{13} \mathrm{C} \mathrm{NMR} \delta_{\mathrm{C}}\left(100 \mathrm{MHz}, \mathrm{CDCl}_{3}\right)$ $173.6,153.2,140.6,136.2,135.9,129.8,129.0,128.9,128.4$, $127.6,127.3,126.7,125.7,124.5,124.2,124.0,123.1,116.9$, $116.0,61.4,54.9,51.1,44.0,33.9,17.8$.

(土)-10b-allyl-5-methyl-5,11-dihydro-10bH-indolo[2,5b] quinoline-11-carboxylic acid methyl ester (12)

A solution of $13(470 \mathrm{mg}, 1.54 \mathrm{mmol})$ in acetone $(20 \mathrm{~mL})$ was added to a stirred mixture of $\mathrm{CrO}_{3}(772 \mathrm{mg}, 7.72 \mathrm{mmol})$ and celite $(2.00 \mathrm{~g})$ in $1.5 \mathrm{M} \mathrm{H}_{2} \mathrm{SO}_{4}(10 \mathrm{~mL})$. After 5 hours, $i-\mathrm{PrOH}(2.0 \mathrm{~mL}$, $26 \mathrm{mmol}$ ) was added and stirring was continued for 0.5 hours. The reaction mixture was filtered through celite and the celite was washed with EtOAc $(50 \mathrm{~mL})$. Brine $(50 \mathrm{~mL})$ was added to the filtrate followed by sufficient $\mathrm{NaHCO}_{3(\mathrm{aq})}$ to neutralise $(\mathrm{pH} 7)$ the aqueous phase. The EtOAc was separated and the aqueous phase was further extracted with EtOAc $(4 \times 50 \mathrm{~mL})$. The combined extracts were dried $\left(\mathrm{MgSO}_{4}\right)$ and the solvent was evaporated at reduced pressure to afford crude 23 . The crude material was dissolved in $\mathrm{MeOH}(20 \mathrm{~mL})$ and $\mathrm{Me}_{3} \mathrm{SiCHN}_{2}(1.54 \mathrm{~mL}$ of a $2.0 \mathrm{M}$ solution in $\left.\mathrm{Et}_{2} \mathrm{O}, 3.08 \mathrm{mmol}\right)$ was added. After stirring for 0.5 hours, $\mathrm{AcOH}(0.5 \mathrm{~mL})$ was added and stirring was continued for an additional 0.5 hours. The solvent was evaporated at reduced pressure and the residue was partitioned between $\mathrm{NaHCO}_{3(\mathrm{aq})}(10$ $\mathrm{mL})$ and $\mathrm{CH}_{2} \mathrm{Cl}_{2}(10 \mathrm{~mL})$. The $\mathrm{CH}_{2} \mathrm{Cl}_{2}$ was separated and the aqueous phase was further extracted with $\mathrm{CH}_{2} \mathrm{Cl}_{2}(3 \times 10 \mathrm{~mL})$. The combined extracts were dried $\left(\mathrm{MgSO}_{4}\right)$ and the solvent was evaporated at reduced pressure. The residue was purified by flash chromatography ( $5 \%$ EtOAc/hexane) to afford the title compound 12 as a colourless crystalline solid $(267 \mathrm{mg}, 0.80 \mathrm{mmol}, 52 \%)$. Mp $137-138{ }^{\circ} \mathrm{C}$; IR (KBr) v $v_{\max }: 2951,1740,1618,1560,1495,1470$, $1400,1215,1161,921,751 \mathrm{~cm}^{-1}$; HRMS (ESI) $\mathrm{m} / z$ calcd for $\mathrm{C}_{21} \mathrm{H}_{21} \mathrm{~N}_{2} \mathrm{O}_{2}$ 333.1603, found 333.1599; ${ }^{1} \mathrm{H}$ NMR $(300 \mathrm{MHz}$, $\left.\mathrm{CDCl}_{3}\right) \delta$ 7.38-7.24 (m, 3H), 7.12-6.99 (m, 4H), 4.97-5.11 (m, 1H), 4.66-4.76 (m, 2H), 4.09 (s, 1H), $3.94(\mathrm{~s}, 3 \mathrm{H}), 3.61(\mathrm{~s}, 3 \mathrm{H}), 2.87$ $(\mathrm{dd}, J=14.0,6.5 \mathrm{~Hz}, 1 \mathrm{H}), 2.55(\mathrm{dd}, J=14.0,8.0 \mathrm{~Hz}, 1 \mathrm{H}) ;{ }^{13} \mathrm{C}$ NMR (75 MHz, $\left.\mathrm{CDCl}_{3}\right) \delta 172.6,172.0,156.0,141.0,136.4,132.4$, $129.2,129.0,127.5,123.0,122.7,122.4,121.2,118.4,117.6$, $114.8,53.3,52.2,49.2,34.7,33.0$.

(土)-10b,11-diallyl-5-methyl-5,11-dihydro-10bH-indolo[2,5b]quinoline-11-carboxylic acid methyl ester (10)

LiHMDS (0.36 mL of a $1.0 \mathrm{M}$ solution in THF, $0.36 \mathrm{mmol})$ was added to a solution of $\mathbf{1 2}(60 \mathrm{mg}, 0.181 \mathrm{mmol})$ in THF $(2 \mathrm{~mL})$ at $78{ }^{\circ} \mathrm{C}$, maintained under an argon atmosphere. The reaction mixture was warmed to $0{ }^{\circ} \mathrm{C}$ and then, after 1 hour, cooled to -78 ${ }^{\circ} \mathrm{C}$. Allyl bromide $(0.047 \mathrm{~mL}, 0.543 \mathrm{mmol})$ was added and the reaction mixture was slowly warmed to room temperature. After 16 hours, $\mathrm{NH}_{4} \mathrm{Cl}_{(\mathrm{aq})}(0.3 \mathrm{~mL})$ was added and the THF was evaporated at reduced pressure. The residue was partitioned between water $(1 \mathrm{~mL})$ and $\mathrm{CH}_{2} \mathrm{Cl}_{2}(2 \mathrm{~mL})$, the $\mathrm{CH}_{2} \mathrm{Cl}_{2}$ was separated and the aqueous phase was further extracted with $\mathrm{CH}_{2} \mathrm{Cl}_{2}(3 \times 2 \mathrm{~mL})$. The combined $\mathrm{CH}_{2} \mathrm{Cl}_{2}$ extracts were dried $\left(\mathrm{MgSO}_{4}\right)$ and the $\mathrm{CH}_{2} \mathrm{Cl}_{2}$ was evaporated at reduced pressure. The crude product was purified by flash chromatography (5\% to $15 \%$ EtOAc/hexane) followed by crystallisation from EtOAc/hexane to afford the title compound $\mathbf{1 0}$ as a colourless crystalline solid (39 $\mathrm{mg}, 0.105 \mathrm{mmol}, 59 \%$ ). Crystals form EtOAc/hexane were suitable for X-ray analysis. Mp $171-173{ }^{\circ} \mathrm{C}$; IR ( $\left.\mathrm{KBr}\right) v_{\max }$ : 2984, $2955,1728,1617,1562,1495,1468,1455,1400,1316,1292$, $1233,1220,935,759 \mathrm{~cm}^{-1}$; HRMS (ESI) $m / z$ calcd for $\mathrm{C}_{24} \mathrm{H}_{25} \mathrm{~N}_{2} \mathrm{O}_{2}$ 373.1916, found 373.1907; ${ }^{1} \mathrm{H}$ NMR $\left(300 \mathrm{MHz}, \mathrm{CDCl}_{3}\right) \delta$ 7.24$7.23(\mathrm{~m}, 3 \mathrm{H}), 7.06-6.97(\mathrm{~m}, 5 \mathrm{H}), 5.47-5.32(\mathrm{~m}, 1 \mathrm{H}), 5.07-4.93(\mathrm{~m}$, $1 \mathrm{H}), 4.84-4.57$ (m, 4H), $3.96(\mathrm{~s}, 3 \mathrm{H}), 3.61(\mathrm{~s}, 3 \mathrm{H}), 2.76(\mathrm{dd}, J=$ $13.5,8.0 \mathrm{~Hz}, 1 \mathrm{H}), 2.63(\mathrm{dd}, J=14.0,7.0 \mathrm{~Hz}, 1 \mathrm{H}), 2.39$ (dd, $J=$
13.5, 6.0 Hz, 1H), $2.03(\mathrm{dd}, J=14.0,7.0 \mathrm{~Hz}, 1 \mathrm{H}) ;{ }^{13} \mathrm{C} \mathrm{NMR}(75$ $\left.\mathrm{MHz}, \mathrm{CDCl}_{3}\right) \delta 172.7,171.7,156.3,140.0,134.7,133.3,132.3$, $131.3,129.0,128.7,123.7,122.9,122.6,121.9,119.0,118.5$, $117.5,114.5,58.3,57.1,52.2,38.5,38.1,33.0$.

(土)-10b-allyl-11-hydroxymethyl-5-methyl-5,11-dihydro-10bHindolo[2,5-b] quinoline-11-carboxylic acid methyl ester (11)

$n$-BuLi $(0.27 \mathrm{~mL}$ of a $1.46 \mathrm{M}$ solution, $0.394 \mathrm{mmol})$ was added to a mixture of $i-\operatorname{Pr}_{2} \mathrm{NH}(0.058 \mathrm{~mL}, 0.412 \mathrm{mmol})$ and THF $(1 \mathrm{~mL})$ at $-78{ }^{\circ} \mathrm{C}$, maintained under an argon atmosphere. The reaction mixture was allowed to warm to room temperature and then, after 0.5 hours, was cooled to $-78{ }^{\circ} \mathrm{C}$ before a solution of $12(65 \mathrm{mg}$, $0.196 \mathrm{mmol})$ in THF $(2 \mathrm{~mL})$ was added. The reaction mixture was warmed to $-10{ }^{\circ} \mathrm{C}$ and after 1 hour formaldehyde, generated by heating paraformaldehyde $(59 \mathrm{mg})$ to $150^{\circ} \mathrm{C}$, was bubbled through the vigorously stirred reaction mixture. The reaction mixture was then allowed to warm to room temperature and was stirred for 1 hour. $\mathrm{NH}_{4} \mathrm{Cl}_{(\mathrm{aq})}(0.5 \mathrm{~mL})$ was added and the THF was evaporated at reduced pressure. The aqueous residue was extracted with $\mathrm{CH}_{2} \mathrm{Cl}_{2}(3 \times 4 \mathrm{~mL})$ and the combined $\mathrm{CH}_{2} \mathrm{Cl}_{2}$ extracts were dried $\left(\mathrm{MgSO}_{4}\right)$. The $\mathrm{CH}_{2} \mathrm{Cl}_{2}$ was evaporated at reduced pressure and the residue was purified by flash chromatography (20\% to $40 \%$ EtOAc/hexane) to afford the title compound $\mathbf{1 1}$ as colourless crystals (55 mg, $0.152 \mathrm{mmol}, 76 \%$ ). Crystals suitable for X-ray analysis were obtained from EtOAc/hexane. Mp 202-203 ${ }^{\circ} \mathrm{C}$; IR (KBr) $v_{\max }: 3240,2954,1733,1618,1561,1497,1470,1455,1406$, $1311,1235,1162,1116,1066,923,805,760,731,643 \mathrm{~cm}^{-1}$; HRMS (ESI) $m / z$ calcd for $\mathrm{C}_{22} \mathrm{H}_{22} \mathrm{~N}_{2} \mathrm{O}_{3} \mathrm{Na}$ 385.1528, found 385.1527; ${ }^{1} \mathrm{H}$ NMR $\left(300 \mathrm{MHz}, \mathrm{CDCl}_{3}\right) \delta 7.36$ (ddd, $J=8.5,7.0$, $1.5 \mathrm{~Hz}, 1 \mathrm{H}), 7.25-7.28(\mathrm{~m}, 2 \mathrm{H}), 6.97-7.15(\mathrm{~m}, 5 \mathrm{H}), 4.92-5.07(\mathrm{~m}$, $1 \mathrm{H}), 4.67-4.79(\mathrm{~m}, 2 \mathrm{H}), 4.01(\mathrm{~s}, 3 \mathrm{H}), 3.91(\mathrm{dd}, J=11.5,6.5 \mathrm{~Hz}$, 1H), 3.59 (s, 3H), 3.38 (dd, $J=11.5,8.0 \mathrm{~Hz}, 1 \mathrm{H}), 2.77$ (dd, $J=$ $13.5,8.0 \mathrm{~Hz}, 1 \mathrm{H}), 2.51$ (dd, $J=13.5,6.5 \mathrm{~Hz}, 1 \mathrm{H}), 1.75(\mathrm{dd}, J=$ 6.5, 8.0 Hz); ${ }^{13} \mathrm{C} \mathrm{NMR}\left(75 \mathrm{MHz}, \mathrm{CDCl}_{3}\right) \delta 172.8,171.5155 .9$, $140.4,134.3,131.7,131.0,129.2,129.2,122.8,122.7,122.53$, $122.50,118.9,117.7,114.8,64.3,58.8,55.8,52.6,38.7,33.0$.

\section{(土)-10b-crotyl-5-benzyl-5,11-dihydro-10bH-indolo[2,5-} b] quinoline-11-carboxylic acid methyl ester (25)

To a stirring mixture of $\mathrm{CrO}_{3}(630 \mathrm{mg}, 6.3 \mathrm{mmol}, 5$ eq. $)$ and celite $(2 \mathrm{~g})$ in $1.5 \mathrm{M} \mathrm{H}_{2} \mathrm{SO}_{4}(10 \mathrm{~mL})$ was added in one portion a solution of $22(500 \mathrm{mg}, 1.18 \mathrm{mmol}, 1 \mathrm{eq}$.) in acetone $(20 \mathrm{~mL})$. After stirring for $5 \mathrm{~h}$ at room temperature, $i-\mathrm{PrOH}(10 \mathrm{~mL})$ was added and the reaction stirred for further $30 \mathrm{~min}$. The mixture was then filtered through celite and the celite washed with additional EtOAc $(10 \mathrm{~mL})$. After adding brine $(10 \mathrm{~mL})$ to the filtrate, and the $\mathrm{pH}$ of the aqueous layer adjusted to $\mathrm{pH} 7$ by addition of saturated aqueous $\mathrm{NaHCO}_{3}$ solution. The organic phase was separated and the aqueous phase further extracted with EtOAc $(4 \times 10 \mathrm{~mL})$. The combined organic extracts were dried $\left(\mathrm{MgSO}_{4}\right)$ and the solvent removed at reduced pressure to afford the crude acid 24. The acid was then dissolved in $\mathrm{MeOH}(20 \mathrm{~mL})$ and $\mathrm{Me}_{3} \mathrm{SiCHN}_{2}(1.25 \mathrm{~mL}$ of a $2.0 \mathrm{M}$ solution in $\mathrm{Et}_{2} \mathrm{O}, 2.36 \mathrm{mmol}$ ) was added. After stirring for $30 \mathrm{~min}$ at room temperature, AcOH $(0.5 \mathrm{~mL})$ was added and the reaction mixture stirred for a further $30 \mathrm{~min}$. After this time the solvent was removed at reduced pressure and the residue partitioned between layers of saturated aqueous $\mathrm{NaHCO}_{3}$ solution $(10 \mathrm{~mL})$ and DCM $(10 \mathrm{~mL})$. The organic phase was separated and the aqueous phase further extracted with DCM $(3 \times 10 \mathrm{~mL})$. The combined extracts were dried $\left(\mathrm{MgSO}_{4}\right)$ and the solvent removed at reduced pressure. The crude product was purified by flash column chromatography (Hexane/EtOAc, 95:5 to 90:10) to afford the desired product $\mathbf{2 5}$ as a colourless crystalline solid (124 mg, $0.29 \mathrm{mmol}, 25 \%$ over two steps). 
Mp 145-147 ${ }^{\circ} \mathrm{C}$; IR (KBr) $v_{\max } 3453,3026,2953,2850,1735$, 1558, $1493 \mathrm{~cm}^{-1}$; HRMS $\left(\right.$ ES $\left.^{+}\right) \mathrm{m} / z$ calcd for $\mathrm{C}_{28} \mathrm{H}_{27} \mathrm{~N}_{2} \mathrm{O}_{2}$ 423.2073, found $423.2071 ;{ }^{1} \mathrm{H} \mathrm{NMR} \delta_{\mathrm{H}}\left(400 \mathrm{MHz}, \mathrm{CDCl}_{3}\right) 7.41-$ $7.14(\mathrm{~m}, 8 \mathrm{H}, \mathrm{ArH}), 7.11-7.09(\mathrm{~m}, 1 \mathrm{H}), 7.06-6.93(\mathrm{~m}, 4 \mathrm{H}), 5.76(\mathrm{~d}$, $J=16.5 \mathrm{~Hz}, 1 \mathrm{H}), 5.27-5.14(\mathrm{~m}, 1 \mathrm{H}), 4.94(\mathrm{~d}, J=16.5 \mathrm{~Hz}, 1 \mathrm{H})$, 4.73-4.60 (m, 1H), $4.14(\mathrm{~s}, 1 \mathrm{H}), 3.94(\mathrm{~s}, 3 \mathrm{H}), 2.91(\mathrm{dd}, J=14.0$ $\mathrm{Hz}, 6.0 \mathrm{~Hz}, 1 \mathrm{H}), 2.62(\mathrm{dd}, J=14.5,8.0 \mathrm{~Hz}, 1 \mathrm{H}), 1.37(\mathrm{dd}$, $J=6.5,0.5 \mathrm{~Hz}, 3 \mathrm{H}) ;{ }^{13} \mathrm{C} \mathrm{NMR} \delta_{\mathrm{C}}\left(100 \mathrm{MHz}, \mathrm{CDCl}_{3}\right) 172.9,171.9$, 155.9, 140.7, 137.0, 136.8, 129.1, 128.9, 128.8 (2C), 127.4, 127.3, $126.9,124.5,123.1,122.7,122.3,121.5,117.7,115.8,53.6,52.1$, $50.2,49.4,33.4,17.9$.

\section{(土)-5-benzy-10b-(2-hydroxyethyl)-5H-indolo[2,3-b]quinolin- 11(10bH)-one (27)}

To a solution of $20(1.00 \mathrm{~g}, 2.74 \mathrm{mmol})$ in THF : $\mathrm{H}_{2} \mathrm{O}(9: 1,20 \mathrm{~mL})$ was added osmium tetroxide $\left(2.5 \mathrm{M}\right.$ solution in ${ }^{t} \mathrm{BuOH}, 0.2 \mathrm{~mL}$, cat.) and NMO (0.97 g, $5.29 \mathrm{mmol}, 2$ eq.) and the mixture stirred at room temperature for $18 \mathrm{~h} . \mathrm{Na}_{2} \mathrm{SO}_{3}$ (aq.) $(20 \mathrm{~mL})$ was added and the resulting mixture stirred for $30 \mathrm{~min}$. Brine $(20 \mathrm{~mL})$ was added and the mixture extracted with DCM $(3 \times 50 \mathrm{~mL})$ before the combined organic layer was dried $\left(\mathrm{MgSO}_{4}\right)$, filtered and concentrated to afford the crude diol as a mixture of diastereoisomers. The crude product was purified by column chromatography $(0-5 \% \mathrm{MeOH} / \mathrm{DCM})$ to give the diol as a yellow solid. To a solution of the diol in DCM $(20 \mathrm{~mL})$ was added iodosobenzene diacetate $(1.06 \mathrm{~g}, 3.29 \mathrm{mmol})$ and the mixture stirred at room temperature for 2 hours. Sodium triacetoxyborohydride $(1.16 \mathrm{~g}, 5.49 \mathrm{mmol})$ was then added and the mixture stirred for a further 2 hours. $\mathrm{NaHCO}_{3}$ (aq.) $(20 \mathrm{~mL})$ was added and the mixture extracted with DCM $(3 \times 20 \mathrm{~mL})$. The combined organic extracts were dried $\left(\mathrm{MgSO}_{4}\right)$, filtered and the solvent removed at reduced pressure to give the crude product. Purification by column chromatography $(20-30 \%$ EtOAc / Hexane) gave 27 as a yellow solid (890 mg, 88\%, 2 steps). Mp 95-97 ${ }^{\circ} \mathrm{C}$; IR (KBr) $v_{\max } 3200,1695,1468,799,755 \mathrm{~cm}^{-1}$; HRMS $\left(\mathrm{ES}^{+}\right): \mathrm{m} / z$ calcd for $\mathrm{C}_{24} \mathrm{H}_{21} \mathrm{~N}_{2} \mathrm{O}_{2} 369.1603$, found: $369.1609 .{ }^{1} \mathrm{H}$ NMR $\delta\left(\mathrm{CDCl}_{3}, 400 \mathrm{MHz}\right) 7.95(\mathrm{dd}, J=7.5,1.5 \mathrm{~Hz}, 1 \mathrm{H}), 7.76$ $(\mathrm{dd}, J=7.5,0.5 \mathrm{~Hz}, 1 \mathrm{H}), 7.51-6.92(\mathrm{~m}, 11 \mathrm{H}), 5.85(\mathrm{~d}, J=16.5 \mathrm{~Hz}$, $1 \mathrm{H}), 5.15(\mathrm{~d}, J=16.5 \mathrm{~Hz}, 1 \mathrm{H}), 2.54-2.40(\mathrm{~m}, 2 \mathrm{H}), 2.21-2.07(\mathrm{~m}$, 2H). ${ }^{13} \mathrm{C}$ NMR $\left(126 \mathrm{MHz}, \mathrm{CDCl}_{3}\right) \delta 193.3,172.6,153.2,144.2$, $135.9,135.7,132.5,129.2,129.0,128.6,127.6,126.6(2 \mathrm{C}), 124.7$, $123.6,123.0,119.1,118.7,115.7,64.7,60.4,50.0,43.2$.

\section{( \pm )-5-benzyl-10b-(2-(benzyloxy)ethyl)-5,10b-}

dihydrospiro[indolo[2,3-b] quinoline-11,2'-oxirane] (28)

To a solution of 27 (50 mg, $0.136 \mathrm{mmol})$ and benzyl TCA (41 mg, $0.163 \mathrm{mmol})$ in DCM (3 mL) was added TMS-OTf ( $30 \mathrm{mg}, 0.136$ mmol) at $0{ }^{\circ} \mathrm{C}$. After stirring for 30 minutes, the ice bath was removed and the reaction stirred for a further 18 hours at room temperature before $\mathrm{NaHCO}_{3}$ (aq.) $(3 \mathrm{~mL})$ was added. The mixture was extracted with DCM (3 $33 \mathrm{~mL})$ before the combined organic extracts were dried $\left(\mathrm{MgSO}_{4}\right)$ filtered and concentrated to give the crude product. The crude was purified by column chromatography (10-20\% EtOAc / Hexane) to give a yellow oil.

To the yellow oil $(122 \mathrm{mg}, 0.266 \mathrm{mmol})$ in THF $(4 \mathrm{~mL})$ at -78 ${ }^{\circ} \mathrm{C}$ was added chloroiodomethane $(29 \mu \mathrm{L}, 0.399 \mathrm{mmol})$ followed by methyl lithium - lithium bromide (1.5 M in THF, $266 \mu \mathrm{L}, 0.399$ mmol). The mixture was stirred at $-78^{\circ} \mathrm{C}$ for 30 minutes before the cold bath was removed and the reaction stirred for a further 5 hours at room temperature before $\mathrm{NH}_{4} \mathrm{Cl}$ (aq.) $(10 \mathrm{~mL})$ was added. The mixture was extracted with DCM $(3 \times 10 \mathrm{~mL})$ before the combined organic extracts were dried $\left(\mathrm{MgSO}_{4}\right)$ filtered and concentrated to give the crude product. The crude was purified by column chromatography (10-20\% EtOAc / Hexane) to give 28 as a yellow oil ( $83 \mathrm{mg}, 51 \%$ - 2 steps).

IR (KBr) $v_{\max }: 1719,1555,1492,1467,1451,1208,750,695 \mathrm{~cm}^{-}$ 1; HRMS $\left(\mathrm{ES}^{+}\right): \mathrm{m} / z$ calcd for $\mathrm{C}_{32} \mathrm{H}_{29} \mathrm{~N}_{2} \mathrm{O}_{2}$ 473.2224, found $473.2217[\mathrm{M}+\mathrm{H}]^{+} ;{ }^{1} \mathrm{H} \mathrm{NMR}\left(400 \mathrm{MHz}, \mathrm{CDCl}_{3}\right) \delta 7.31-7.04(\mathrm{~m}$, $16 \mathrm{H}), 6.93(\mathrm{td}, J=7.5,1.0 \mathrm{~Hz}, 1 \mathrm{H}), 6.81(\mathrm{dd}, J=8.0,0.5 \mathrm{~Hz}, 1 \mathrm{H})$, $5.66(\mathrm{~d}, J=16.5 \mathrm{~Hz}, 1 \mathrm{H}), 4.89(\mathrm{~d}, J=16.5 \mathrm{~Hz}, 1 \mathrm{H}), 4.10(\mathrm{~s}, 2 \mathrm{H})$, $3.15-3.02(\mathrm{~m}, 2 \mathrm{H}), 2.97(\mathrm{~d}, J=5.5 \mathrm{~Hz}, 1 \mathrm{H}), 2.46(\mathrm{~d}, J=5.5 \mathrm{~Hz}$, 1H), $2.42-2.27(\mathrm{~m}, 2 \mathrm{H}) ;{ }^{13} \mathrm{C}$ NMR $\left(101 \mathrm{MHz}, \mathrm{CDCl}_{3}\right) \delta 172.8$, 155.6, 141.1, 138.1, 136.8, 134.0, 129.4, 129.0 (2C), $128.8(2 \mathrm{C})$, $128.3,127.6(2 \mathrm{C}), 127.5,127.2,126.4(2 \mathrm{C}), 123.7,123.2,123.1$, $122.9,122.8,118.2,115.1,73.1,66.5,60.5,53.7,53.3,49.6,33.6$.

\section{(土)-5-benzyl-10b-(2-((tert-butyldiphenylsilyl)oxy)ethyl)-5,10b-} dihydrospiro[indolo[2,3-b]quinoline-11,2'-oxirane] (30)

To a solution of $27(4.60 \mathrm{~g}, 12.5 \mathrm{mmol})$ in DCM $(140 \mathrm{~mL})$ at room temperature was added tert-butyl diphenyl silyl chloride (4.12 g, $15.0 \mathrm{mmol})$ and imidazole $(1.88 \mathrm{~g}, 27.6 \mathrm{mmol})$. The mixture was stirred at room temperature for 60 minutes before $\mathrm{NH}_{4} \mathrm{Cl}_{\text {(aq.) }}(100$ $\mathrm{mL})$ was added and the mixture extracted with DCM $(3 \times 100 \mathrm{~mL})$. The combined organic layer dried $\left(\mathrm{MgSO}_{4}\right)$, filtered and concentrated to give the crude product. Purification by column chromatography (5-15\% EtOAc / Hexane) to give a yellow solid.

The yellow solid (380 mg, $0.626 \mathrm{mmol}$ ) was taken up in THF $(10 \mathrm{~mL})$ at $-78{ }^{\circ} \mathrm{C}$ was added chloroiodomethane $(69 \mu \mathrm{L}, 0.939$ mmol) followed by the dropwise addition of methyl lithium lithium bromide $(1.5 \mathrm{M}$ in THF, $626 \mu \mathrm{L}, 0.939 \mathrm{mmol})$. The mixture was stirred at $-78{ }^{\circ} \mathrm{C}$ for 15 minutes before the cold bath was removed and the reaction stirred for a further 5 hours at room temperature. $\mathrm{NH}_{4} \mathrm{Cl}$ (aq.) $(30 \mathrm{~mL})$ was added and the mixture extracted with DCM $(3 \times 30 \mathrm{~mL})$ before the combined organic extracts were dried $\left(\mathrm{MgSO}_{4}\right)$ filtered and concentrated to give the crude product. The crude was purified by column chromatography (10-20\% EtOAc / Hexane) to give $\mathbf{3 0}$ as a yellow solid (330 $\mathrm{mg}$, $71 \%$ - 2 steps). Mp 46-49 ${ }^{\circ} \mathrm{C}$; IR (KBr) v $\max$ : 3069, 3044, 2926, 2852, 1807, 1558, 1452, 1108, $700 \mathrm{~cm}^{-1}$; HRMS $\left(\mathrm{ES}^{+}\right) \mathrm{m} / z$ calcd for $\mathrm{C}_{41} \mathrm{H}_{40} \mathrm{~N}_{2} \mathrm{O}_{2} \mathrm{NaSi}$ 643.2757, found $643.2762[\mathrm{M}+\mathrm{Na}]^{+} ;{ }^{1} \mathrm{H}$ NMR (300 MHz, $\left.\mathrm{CDCl}_{3}\right) \delta 7.53-7.08(\mathrm{~m}, 19 \mathrm{H}), 7.08-6.93(\mathrm{~m}$, $2 \mathrm{H}), 6.93-6.75(\mathrm{~m}, 2 \mathrm{H}), 5.53(\mathrm{~d}, J=16.5 \mathrm{~Hz}, 1 \mathrm{H}), 5.03(\mathrm{~d}, J=$ $16.5 \mathrm{~Hz}, 1 \mathrm{H}), 3.50-3.38$ (ddd, $J=10.0,9.0,5.5 \mathrm{~Hz}, 1 \mathrm{H}), 3.26$ (ddd, $J=10.0,9.0,5.5 \mathrm{~Hz}, 1 \mathrm{H}), 2.93$ (d, $J=5.5 \mathrm{~Hz}, 1 \mathrm{H}), 2.43$ (d, $J=5.5 \mathrm{~Hz}, 1 \mathrm{H}), 2.25$ (tdd, $J=13.5,9.0,6.0 \mathrm{~Hz}, 2 \mathrm{H}), 0.83(\mathrm{~s}, 9 \mathrm{H})$; ${ }^{13} \mathrm{C}$ NMR $\left(101 \mathrm{MHz}, \mathrm{CDCl}_{3}\right) \delta 172.6,155.3,140.8,136.6,135.4$ (4C), 133.9, 133.5, 133.4, 129.5, 129.4, 129.3, 128.8 (3C), 127.6 (2C), 127.5 (2C), 127.2, 126.5 (2C), 123.7, 123.2, 122.9, 122.7, $118.1,115.1,60.4,60.1,53.5,53.1), 49.4,36.3,26.8,19.0$.

(土)-(-5-benzyl-10b-(2-((tert-butyldiphenylsilyl)oxy)ethyl)-10b,11dihydro-5H-indolo[2,3-b]quinolin-11-yl)methanol (31)

To a solution of $\mathbf{3 0}(135 \mathrm{mg}, 0.218 \mathrm{mmol})$ in THF (4 mL) at -78 ${ }^{\circ} \mathrm{C}$ was added boron trifluoride diethyl etherate $(135 \mu \mathrm{L}, 1.090$ mmol) followed by sodium cyanoborohydride (34 mg, 0.545 mmol). The mixture was slowly allowed to warm to room temperature over a period of 4 hours before stirring for a further 12 hours at room temperature. $\mathrm{NH}_{4} \mathrm{Cl}$ (aq.) $(10 \mathrm{~mL})$ was added before the mixture being extracted with DCM $(3 \times 10 \mathrm{~mL})$ and the combined organic layer dried $\left(\mathrm{MgSO}_{4}\right)$, filtered and concentrated to give the crude product. Purification by column chromatography (20-40\% EtOAc / Hexane) gave 31 as a white solid (74 mg, 55\%). Mp 112-115 ${ }^{\circ}$ C; I.R. (KBr) v $v_{\max }: 3212$, 2926, 2251, 1644, 1555, 1496, 1191, 1103, $700 \mathrm{~cm}^{-1}$; HRMS $\left(\mathrm{ES}^{+}\right): \mathrm{m} / \mathrm{z}$ calcd for $\mathrm{C}_{41} \mathrm{H}_{43} \mathrm{~N}_{2} \mathrm{O}_{2} \mathrm{Si}$ 623.3088, found $623.0383[\mathrm{M}+\mathrm{H}]^{+} ;{ }^{1} \mathrm{H}$ NMR $(300$ $\left.\mathrm{MHz}, \mathrm{CDCl}_{3}\right) \delta 7.54(\mathrm{~d}, J=7.5 \mathrm{~Hz}, 1 \mathrm{H}), 7.39-7.00(\mathrm{~m}, 19 \mathrm{H})$, 
$6.94(\mathrm{t}, J=7.5 \mathrm{~Hz}, 1 \mathrm{H}), 6.87-6.77(\mathrm{~m}, 2 \mathrm{H}), 5.28(\mathrm{~d}, J=16.5 \mathrm{~Hz}$, $1 \mathrm{H}), 4.96(\mathrm{~d}, J=16.5 \mathrm{~Hz}, 1 \mathrm{H}), 4.53-4.39(\mathrm{~m}, 1 \mathrm{H}), 4.31-4.17$ $(\mathrm{m}, 1 \mathrm{H}), 3.30-3.12(\mathrm{~m}, 1 \mathrm{H}), 3.01-2.81(\mathrm{~m}, 2 \mathrm{H}), 2.01$ (ddd, $J=$ $13.5,9.0,5.0 \mathrm{~Hz}, 1 \mathrm{H}$ ), 1.80 (ddd, $J=13.5,9.0,5.0 \mathrm{~Hz}, 1 \mathrm{H}$ ), 0.80 (s, 9H); ${ }^{13} \mathrm{C}$ NMR $\left(101 \mathrm{MHz}, \mathrm{CDCl}_{3}\right) \delta 174.1,156.0,140.6,136.9$, 136.5, 135.4, 135.3 (2C), 133.6, 133.5, 129.5, 128.7 (2C), 127.9, 127.5 (2C), 127.1 (2C), 126.7 (2C), 125.4, 123.5, 123.3, 122.3, $117.7,115.6,61.7,60.2,52.3,49.6,44.9,33.0,26.8,19.0$.

(土)-5-benzyl-10b-(2-((tert-butyldiphenylsilyl)oxy)ethyl)-11hydroxy-10b,11-dihydro-5H-indolo[2,3-b]quinoline-11carbaldehyde (33)

To a solution of $\mathbf{3 1}(75 \mathrm{mg}, 0.120 \mathrm{mmol})$ in $\mathrm{CDCl}_{3}(3 \mathrm{~mL})$ was added Dess-Martin periodinane $(61 \mathrm{mg}, 0.144 \mathrm{mmol})$ and the mixture was stirred at room temperature for 48 hours. $\mathrm{Na}_{2} \mathrm{~S}_{2} \mathrm{O}_{3}$ (aq.) $(3 \mathrm{~mL})$ and $\mathrm{NaHCO}_{3}$ (aq.) $(3 \mathrm{~mL})$ were added and the mixture stirred for a further 30 minutes before the mixture was extracted with DCM $(3 \times 5 \mathrm{~mL})$. The combined organic layers were dried $\left(\mathrm{MgSO}_{4}\right)$, filtered and concentrated to give the crude product 32 . Purification by column chromatography (10-25 \% EtOAc / Hexane) gave 33 as a white solid (50 mg, 65\%). M.p. 101-103 ${ }^{\circ} \mathrm{C}$; I.R. (KBr) $v_{\max }: 3435,3063,2928,2855,1725,1556,1467,1453$, 1207, 1110, 821, 737, 701, $503 \mathrm{~cm}^{-1}$; HRMS (ES-): $\mathrm{m} / \mathrm{z}$ calcd for $\mathrm{C}_{41} \mathrm{H}_{39} \mathrm{~N}_{2} \mathrm{O}_{3} \mathrm{Si}$ 635.2730, found 635.2722 [M-H] ${ }^{-}{ }^{1} \mathrm{H}$ NMR $(400$ $\left.\mathrm{MHz}, \mathrm{CDCl}_{3}\right) \delta 9.08(\mathrm{~d}, J=1.0 \mathrm{~Hz}, 1 \mathrm{H}), 7.50(\mathrm{~m}, 2 \mathrm{H}), 7.44-7.22$ $(\mathrm{m}, 18 \mathrm{H}), 7.07(\mathrm{t}, J=7.5 \mathrm{~Hz}, 1 \mathrm{H}), 7.01-6.95(\mathrm{~m}, 2 \mathrm{H}), 5.53(\mathrm{~d}, J$ $=16.5 \mathrm{~Hz}, 1 \mathrm{H}), 5.25(\mathrm{~s}, 1 \mathrm{H}), 5.20(\mathrm{~d}, J=16.5 \mathrm{~Hz}, 1 \mathrm{H}), 3.43(\mathrm{t}, J$ $=7.0 \mathrm{~Hz}, 2 \mathrm{H}), 2.43(\mathrm{dt}, J=14.0,7.0 \mathrm{~Hz}, 1 \mathrm{H}), 1.97(\mathrm{dt}, J=14.0$, $6.0 \mathrm{~Hz}, 1 \mathrm{H}), 0.98(\mathrm{~s}, 9 \mathrm{H}) ;{ }^{13} \mathrm{C} \mathrm{NMR}\left(101 \mathrm{MHz}, \mathrm{CDCl}_{3}\right) \delta 196.7$, 172.6, 155.6, 140.0, 136.6, 135.5 (2C), 135.4 (2C), 134.0, 132.9, $132.7,130.2,129.7,129.7,129.2,128.8$ (2C), 127.7 (2C), 127.6 (2C), 127.4, 127.0, 126.9 (2C), 123.7, 123.4, 123.1, 122.3, 118.3, $115.5,81.6,60.0,55.4,49.3,34.6,26.8,19.1$.

\section{1-allyl-5-methyl-5H-indolo[2,3-b]quinoline (35)}

$t$-BuOK $(0.83 \mathrm{~mL}$ of a $1.0 \mathrm{M}$ solution in $t$-BuOH, $0.830 \mathrm{mmol})$ was added to a stirred mixture of 5,10b-dihydro-10b-allyl-5methyl-10b $H$-indolo[2,3-b]quinolin-11-one (14) (100 mg, 0.347 $\mathrm{mmol})$, TosMIC ( $88 \mathrm{mg}, 0.451 \mathrm{mmol})$ and DME $(2.5 \mathrm{~mL})$ that was cooled to $0{ }^{\circ} \mathrm{C}$ and maintained under an argon atmosphere. After 0.5 hours, the reaction mixture was allowed to warm to room temperature and the stirring was continued for 1 hour. Water (2 $\mathrm{mL})$ was added and the mixture was extracted with $\mathrm{CH}_{2} \mathrm{Cl}_{2}(3 \times 5$ $\mathrm{mL})$. The combined extracts were washed with brine $(10 \mathrm{~mL})$ and then dried $\left(\mathrm{MgSO}_{4}\right)$. The solvent was evaporated at reduced pressure and the residue was purified by flash chromatography (50\% to $80 \%$ EtOAc/hexane) to afford the title compound $\mathbf{3 5}$ as an orange solid (57 mg, $0.209 \mathrm{mmol}, 61 \%)$. Mp 125-127 ${ }^{\circ} \mathrm{C}$; IR (KBr) $v_{\text {max }}: 3049,1627,1608,1565,1525 \mathrm{~cm}^{-1}$; HRMS (EI) m/z calcd for $\mathrm{C}_{19} \mathrm{H}_{16} \mathrm{~N}_{2} \mathrm{O}$ 272.1313, found 272.1317; ${ }^{1} \mathrm{H}$ NMR $(500$ $\left.\mathrm{MHz}, \mathrm{CDCl}_{3}\right) \delta 8.17(\mathrm{~d}, J=8.0 \mathrm{~Hz}, 1 \mathrm{H}), 8.08(\mathrm{~d}, J=7.5 \mathrm{~Hz}, 1 \mathrm{H})$, 7.78-7.73 (m, 3H), $7.54(\mathrm{t}, J=7.5 \mathrm{~Hz}, 1 \mathrm{H}), 7.49-7.45(\mathrm{~m}, 1 \mathrm{H})$, 7.24 (t, $J=7.5 \mathrm{~Hz}, 1 \mathrm{H}), 6.19$ (ddt, $J=16.5,10.5,5.5 \mathrm{~Hz}, 1 \mathrm{H})$, 5.18-5.13 (m, 2H), 4.35-4.31 (m, 5H); ${ }^{13} \mathrm{C}$ NMR (101 MHz, $\left.\mathrm{CDCl}_{3}\right) \delta 155.8,155.3,141.0,137.1,133.3,130.4,128.9,126.0$, $124.3,123.3,122.0,120.8,120.0,117.82,117.79,114.7,33.3$, 33.0.

( \pm -10b-(2',2'-dimethyl[1,3]dioxolan-4'-ylmethyl)-5-methyl5,10b-dihydroindolo[2,3-b]quinolin-11-one (36) and (土)-10b$\left(2^{\prime}, 2^{\prime}\right.$-dimethyl 1,3$]$ dioxolan-4'-ylmethyl)-5-methyl-5,10bdihydroindolo[2,3-b]quinolin-11-one (36*)
Osmium tetroxide $(3.26 \mathrm{~mL}$ of a $2.5 \%$ solution in $t-\mathrm{BuOH})$ was added to a vigorously stirred solution of 5,10b-dihydro-10b-allyl5-methyl-10bH-indolo[2,3-b]quinolin-11-one (130) (1.50 g, 5.20 $\mathrm{mmol})$ and NMO $(1.28 \mathrm{~g}, 10.9 \mathrm{mmol})$ in THF/water $(9: 1,40 \mathrm{~mL})$. After 24 hours a saturated solution of sodium sulphite $(90 \mathrm{~mL})$ was added and stirring was continued for 0.5 hours before the reaction mixture was extracted with $\mathrm{CH}_{2} \mathrm{Cl}_{2}(3 \times 150 \mathrm{~mL})$. The combined $\mathrm{CH}_{2} \mathrm{Cl}_{2}$ extracts were washed with brine $(200 \mathrm{~mL})$, dried $\left(\mathrm{MgSO}_{4}\right)$ and the solvent was evaporated at reduced pressure. The residue was triturated with $\mathrm{Et}_{2} \mathrm{O}$ and the yellow solids were collected by filtration.

2,2-dimethoxypropane $(9.57 \mathrm{~mL}, 78.0 \mathrm{mmol})$ and PPTS $(1.31$ g, $5.21 \mathrm{mmol}$ ) were added to a stirred suspension of the crude solid in $\mathrm{CH}_{2} \mathrm{Cl}_{2}(100 \mathrm{~mL})$, maintained under an argon atmosphere. After 2 days, when all the solids had gone into solution, $\mathrm{NaHCO}_{3(\mathrm{aq})}(50$ $\mathrm{mL}$ ) was added and the $\mathrm{CH}_{2} \mathrm{Cl}_{2}$ was separated. The aqueous phase was further extracted with $\mathrm{CH}_{2} \mathrm{Cl}_{2}(3 \times 25 \mathrm{~mL})$. The combined extracts were dried $\left(\mathrm{MgSO}_{4}\right)$ and the solvent was evaporated at reduced pressure. The residue was purified by flash chromatography (5\% to $10 \%$ EtOAc/hexane) to yield the title compounds 36/36* as a 1:1 mixture of diastereomers $(1.32 \mathrm{~g}, 3.64$ mmol, $70 \%$ ). Whilst complete separation of the diastereomers could not be achieved, small highly enriched samples of each diastereomer could be obtained (122 $\mathrm{mg}$ of the less polar isomer and $50 \mathrm{mg}$ of the more polar) by careful flash chromatography. Less polar isomer: IR (film) $v_{\max }: 2986,2937,1694,1563 \mathrm{~cm}^{-1}$; HRMS (CI) m/z calcd for $\mathrm{C}_{22} \mathrm{H}_{23} \mathrm{~N}_{2} \mathrm{O}_{3} 363.1709$, found 363.1698; ${ }^{1} \mathrm{H}$ NMR $\left(400 \mathrm{MHz}, \mathrm{CDCl}_{3}\right) \delta 7.92(\mathrm{dd}, J=7.5,1.5 \mathrm{~Hz}, 1 \mathrm{H}), 7.70$ $(\mathrm{d}, J=7.0 \mathrm{~Hz} 1 \mathrm{H}), 7.58(\mathrm{t}, J=8.0 \mathrm{~Hz}, 1 \mathrm{H}), 7.43(\mathrm{~d}, J=7.5 \mathrm{~Hz}$, $1 \mathrm{H}), 7.36(\mathrm{td}, J=7.5,1.5 \mathrm{~Hz}, 1 \mathrm{H}), 7.18-7.06(\mathrm{~m}, 3 \mathrm{H}), 3.69(\mathrm{~s}, 3 \mathrm{H})$, $3.58-3.51(\mathrm{~m}, 1 \mathrm{H}), 3.27(\mathrm{dd}, J=8.5,6.0 \mathrm{~Hz}, 1 \mathrm{H}), 3.01(\mathrm{dd}, J=8.5$, $6.0 \mathrm{~Hz}, 1 \mathrm{H}), 2.45(\mathrm{dd}, J=13.5,5.5 \mathrm{~Hz}, 1 \mathrm{H}), 2.18(\mathrm{dd}, J=13.5,7.0$ $\mathrm{Hz}, 1 \mathrm{H}), 1.22(\mathrm{~s}, 3 \mathrm{H}), 1.17(\mathrm{~s}, 3 \mathrm{H}) ;{ }^{13} \mathrm{C} \mathrm{NMR}\left(101 \mathrm{MHz}, \mathrm{CDCl}_{3}\right)$ $\delta 193.2,172.3,153.9,145.4,136.1,132.4,129.3,128.6,124.7$, $123.4,122.3,118.8,118.4,114.5,108.4,72.0,69.3,64.4,44.6$, 33.3, 26.8, 25.6.

More polar isomer: IR (film) $v_{\max }: 2986,2937,1696$, HRMS (CI) $\mathrm{m} / \mathrm{z}$ calcd for $\mathrm{C}_{22} \mathrm{H}_{23} \mathrm{~N}_{2} \mathrm{O}_{3} 363.1709$, found 363.1700; ${ }^{1} \mathrm{H}$ NMR $\left(300 \mathrm{MHz}, \mathrm{CDCl}_{3}\right) \delta 7.94(\mathrm{dd}, J=8.5,1.5 \mathrm{~Hz}, 1 \mathrm{H}), 7.77(\mathrm{~d}, J=$ $7.5 \mathrm{~Hz}, 1 \mathrm{H}), 7.61(\mathrm{td}, J=8.0,1.5 \mathrm{~Hz}, 1 \mathrm{H}), 7.44-7.34(\mathrm{~m}, 2 \mathrm{H}), 7.21-$ $7.11(\mathrm{~m}, 3 \mathrm{H}), 3.91-3.82(\mathrm{~m}, 2 \mathrm{H}), 3.71(\mathrm{~s}, 3 \mathrm{H}), 3.33-3.26(\mathrm{~m}, 1 \mathrm{H})$, $2.51(\mathrm{dd}, J=13.5,6.0 \mathrm{~Hz}, 1 \mathrm{H}), 1.88(\mathrm{dd}, J=13.5,6.0 \mathrm{~Hz}, 1 \mathrm{H})$, 1.89 (s, 3H), 1.15 (s, 3H); ${ }^{13} \mathrm{C}$ NMR (101 MHz, $\left.\mathrm{CDCl}_{3}\right) \delta 193.1$, $173.0,153.7,145.0,135.8,133.0,129.2,128.9,125.0,123.5$, $122.7,119.5,118.9,114.6,109.0,72.1,69.3,64.6,45.6,33.3$, $26.8,25.4$.

Preparation of ( \pm )-11-allyl-10b-(2,2-dimethyl[1,3]dioxolan-4ylmethyl)-5-methyl-5,11-dihydro-10bH-indolo[2,3-b]quinolin11-carbonitrile (38) via ( \pm -10b-((2,2-dimethyl-1,3-dioxolan-4yl)methyl)-5-methyl-10b,11-dihydro-5H-indolo[2,3-b]quinoline11-carbonitrile (37) and epi ( \pm -10b-((2,2-dimethyl-1,3-dioxolan4-yl)methyl)-5-methyl-10b,11-dihydro-5H-indolo[2,3-

b] quinoline-11-carbonitrile (37*)

$t$-BuOK $(0.73 \mathrm{~mL}$ of a $1.0 \mathrm{M}$ solution in $t-\mathrm{BuOH}, 0.730 \mathrm{mmol})$ was added to a stirred mixture of enriched $36(110 \mathrm{mg}, 0.304$ $\mathrm{mmol})$, TosMIC (77 mg, $0.396 \mathrm{mmol})$ and DME (2.5 mL), cooled to $0{ }^{\circ} \mathrm{C}$ and maintained under an argon atmosphere. After 0.5 hours, the reaction mixture was allowed to warm to room temperature and the stirring was continued for 0.5 hour. Water ( 2 $\mathrm{mL})$ was added and the mixture was extracted with $\mathrm{CH}_{2} \mathrm{Cl}_{2}(3 \times 5$ $\mathrm{mL})$. The combined extracts were washed with brine $(10 \mathrm{~mL})$ and then dried $\left(\mathrm{MgSO}_{4}\right)$. The solvent was evaporated at reduced pressure and the residue was purified by flash chromatography (5\% to $10 \%$ EtOAc/hexane) to afford a sample that was 
predominantly 37 as a mixture of diastereomers $(37 *=$ minor isomer) that could not be separated $(59 \mathrm{mg})$. IR ( $\mathrm{KBr}) v_{\max }: 2985$, 2934, 2243, $1562 \mathrm{~cm}^{-1}$; HRMS (CI) m/z calcd for $\mathrm{C}_{23} \mathrm{H}_{24} \mathrm{~N}_{3} \mathrm{O}_{2}$ 374.1869, found 374.1858; ${ }^{1} \mathrm{H}$ NMR $\left(400 \mathrm{MHz}, \mathrm{CDCl}_{3}\right) \delta 7.59-$ 7.54 (m, 2H-major and 2H-minor), $7.45-7.30$ (m, 3H-major and $3 \mathrm{H}$-minor), $7.28-7.25$ (m, 1H-minor), 7.22 (d, $J=7.2 \mathrm{~Hz}$, 1H-minor), $7.16-7.04$ (m, 3H-major and 1H-minor), 4.23 (s, 1H-major), 4.16 (s, 1H-minor), 3.67 (s, 3H-minor), 3.59 (s, 3Hmajor), 3.50 (q, $J=6.0 \mathrm{~Hz}, 1 \mathrm{H}$-minor), 3.42 (q, $J=6.0 \mathrm{~Hz}, 1 \mathrm{H}-$ major), $3.26-3.18$ (m, 1H-major and $1 \mathrm{H}$-minor), $3.07-3.02$ (m, 1H-major), 2.95 (dd, $J=8.5,6.5 \mathrm{~Hz}, 1 \mathrm{H}$-minor), $2.29-$ 2.21 (m, 1H-major and $1 \mathrm{H}$ minor), $2.12-2.05$ ( $\mathrm{m}, 1 \mathrm{H}$-major), 1.75 (dd, $J=13.5,6.5 \mathrm{~Hz}, 1 \mathrm{H}$-minor), $1.19-1.13$ (m, $6 \mathrm{H}$ major and $6 \mathrm{H}$ minor).

This mixture of diastereomers $(59 \mathrm{mg})$ was dissolved in THF $(1 \mathrm{~mL})$ and cooled to $-78{ }^{\circ} \mathrm{C}$, under an argon atmosphere. LiHMDS $(0.24 \mathrm{~mL}$ of a $1.0 \mathrm{M}$ solution in THF) was added and the reaction mixture was warmed to $0{ }^{\circ} \mathrm{C}$ for 0.5 hours. The orange reaction mixture was then cooled to $-78{ }^{\circ} \mathrm{C}$ and allyl bromide $(27$ $\mu \mathrm{L}, 0.312 \mathrm{mmol}$ ) was added. After stirring $-78^{\circ} \mathrm{C}$ for 2 hours, the reaction mixture slowly warmed to room temperature and stirred for a further 16 hours. $\mathrm{NH}_{4} \mathrm{Cl}_{(\mathrm{aq})}(0.5 \mathrm{~mL})$ was added and the solvent was evaporated at reduced pressure. The residue was partitioned between $\mathrm{CH}_{2} \mathrm{Cl}_{2}(1 \mathrm{~mL})$ and water $(1 \mathrm{~mL})$. The $\mathrm{CH}_{2} \mathrm{Cl}_{2}$ was separated and the aqueous phase was further extracted with $\mathrm{CH}_{2} \mathrm{Cl}_{2}(3 \times 1 \mathrm{~mL})$. The combined extracts were dried $\left(\mathrm{MgSO}_{4}\right)$ and the solvent was evaporated at reduced pressure. The residue was purified by chromatography (5\% to $10 \%$ EtOAc/hexane) to afford 38 as a colourless oil (43 mg, $0.104 \mathrm{mmol}, 34 \%$ ). IR (film) $v_{\max }$ : 2985, 2241, 1564; HRMS (EI) m/z calcd for $\mathrm{C}_{26} \mathrm{H}_{27} \mathrm{~N}_{3} \mathrm{O}_{2}$ 413.2103, found 413.1998; ${ }^{1} \mathrm{H} \mathrm{NMR}\left(400 \mathrm{MHz}, \mathrm{CDCl}_{3}\right) \delta 7.50(\mathrm{~d}$, $J=7.5 \mathrm{~Hz}, 1 \mathrm{H}), 7.43-7.31(\mathrm{~m}, 4 \mathrm{H}), 7.12-7.03$ (m, 3H, 3 x ArH), 5.49-5.38 (m, 1H,), 5.05-5.01 (m, 1H), 4.87-4.82 (m, 1H), $3.61(\mathrm{~s}$, $3 \mathrm{H}), 3.43-4.39(\mathrm{~m}, 1 \mathrm{H}), 3.26(\mathrm{dd}, J=8.5,6.0 \mathrm{~Hz}, 1 \mathrm{H}), 3.06(\mathrm{dd}, J$ $=8.5,6.5 \mathrm{~Hz}, 1 \mathrm{H}), 2.39(\mathrm{dd}, J=14.0,6.5 \mathrm{~Hz}, 1 \mathrm{H}), 2.24-2.33(\mathrm{~m}$, $2 \mathrm{H}), 2.18(\mathrm{dd}, J=14.0,7.0 \mathrm{~Hz}, 1 \mathrm{H}), 1.18(\mathrm{~s}, 3 \mathrm{H}), 1.15(\mathrm{~s}, 3 \mathrm{H}) ;{ }^{13} \mathrm{C}$ NMR $\left(101 \mathrm{MHz}, \mathrm{CDCl}_{3}\right) \delta 170.9,156.4,138.8,133.3,130.7$, $130.20,130.17,129.3,123.4,123.0,122.5,121.0,120.5,119.6$, 118.2, 115.3, 108.5, 72.2, 69.6, 55.3, 49.5, 38.9, 38.6, 33.0, 26.9, 25.7.

\section{Acknowledgments}

We would like to acknowledge EPSRC for PhD funding through the Doctoral Training Schemes and the EPSRC National Mass Spectrometry Service Center, Swansea for mass spec analysis.

\section{References and notes}

1. Verbitski SM, Mayne CL, Davis RA, Concepcion GP, Ireland CM. $J$ Org Chem. 2002; 67: 7124-7126.

2. For selected reviews, see Trost BM, Osipov M. Chem Eur J. 2015; 21: 16318-16343; b) Siengalewicz P, Gaich T, Mulzer J. Angew Chem Int Ed. 2008; 47: 8170-8176.

3. For total and formal syntheses of perophoramidine, see a) Fuchs JR, Funk RL. J Am Chem Soc. 2004; 126 (16): 5068-5069; b) Wu H, Xue F, Xiao X, Qin Y. J Am Chem Soc. 2010; 132 (40): 14052-14054 c) Zhang H, Hong L, Kang H, Wang R. J Am Chem Soc. 2013; 135 (38): 14098-14101 d) Han SJ, Vogt F, May JA, Krishnan S, Gatti M, Virgil SC, Stoltz BM, J Org Chem. 2015; 80: 528-547; e) Han SJ, Vogt F, May JA, Krishnan S, Gatti M, Virgil SC, Stoltz BM, Org Lett. 2014; 16: 3316-3319; f) Trost BM, Osipov M, Krüger S, Zhang Y. Chem Sci. 2015; 6 (1): 349-353. For additional approaches aimed at perophoramidine, see g) Artman III GD, Weinreb SM. Org Lett. 2003; 5 (9): 1523-1526; h) Yang J, Song H, Xiao X, Wang J, Qin Y. Org Lett. 2006; 8 (10): 2187-2190; i) Wu L, Zhang Q-R, Huang J-R, Li Y, Su F, Dong L, Tetrahedron, 2017; 73: 3966-3972.

4. For total syntheses of dehaloperophoramidine, see a) Sabahi A, Novikov AJ, Rainier D. Angew Chem Int Ed. 2006; 45: 4317-4320; b) Ishida T, Ikota H, Kurahashi K, Tsukano C, Takemoto Y. Angew Chem Int Ed. 2013; 52: 10204-10207; c) Popov K, Hoang A, Somfai P. Angew. Chem Int Ed. 2016; 55: 1801-1804; d) Wilkie RP, Neal AR, Johnston CA, Voute N, Lancefield CA, Stell MD, Medda F, Makiyi EF, Turner EM, Ojo OS, Slawin AMZ, Lebl T, Mullen P, Harrison DJ, Ireland CM, Westwood NJ. Chem Commun. 2016; 52: 10747-10750; e) Hoang A, Popov K, Somfai P. J Org Chem. 2017; 82: 2171-2176.

5. For total syntheses of the Communesins A, B and F see a) Yang J, Wu H, Shen L, Qin Y. J Am Chem Soc. 2007; 129: 13794-13795; b) Yang J, Wu H, Shen L, Qin Y. Synfacts. 2008; 226; c) Liu P, Seo JH, Weinreb SM, Angew Chem Int Ed. 2010; 49: 2000-2003; d) Zuo Z, Xie W, Ma D. J Am Chem Soc. 2010; 132: 13226-13228; e) Zuo Z, Ma D. Angew Chem Int Ed. 2011; 50: 12008-12011; f) Belmar J, Funk RL. J Am Chem Soc. 2012; 134: 16941-16943; g) Lathrop SP, Pompeo M, Chang W-TT, Movassaghi M, J Am Chem Soc. 2016; 138: 7763-7769; h) Liang X, Zhang T-Y, Zeng X-Y, Zheng Y, Wei K, Yang Y-R, $J$ Am Chem Soc. 2017; 139: 3364-3367.

6. Voute N, Philp D, Slawin AMZ, Westwood NJ. Org Biomol Chem. 2010; 8: 442-450.

7. Boger DL, Hueter L, Mbiya K, Zhang, M. J Am Chem Soc. 1995; 117 : 11839-11849.

\section{Supplementary Material}

Crystallographic data (excluding structure factors) for the structures in this paper have been deposited with the Cambridge Crystallographic Data Centre as supplementary publication numbers CCDC 1582892 (10); CCDC 1582893 (22); CCDC 1582894 (15); CCDC 1582895 (19); CCDC 1582896 (11); CCDC 1582897 (13).

Additional results, discussion and discussion of supplementary compounds are discussed in the ESI. 